\title{
Stratigraphic Notes, 1985-86
}

\section{U.S. GEOLOGICAL SURVEY BULLETIN 1775-A}

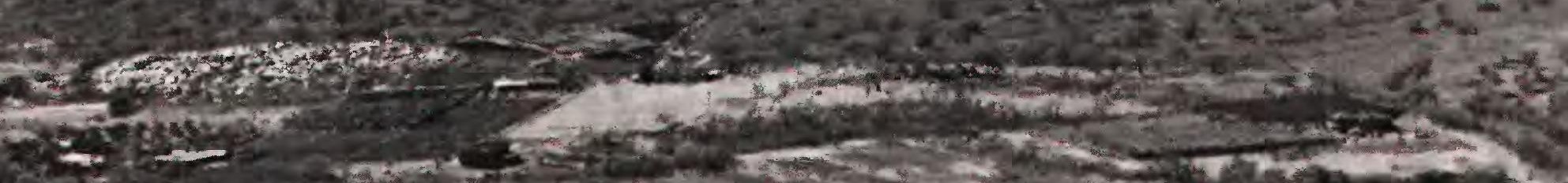


COVER PHOTOGRAPH: View looking northwest from Mauna Kuwale at Kamaileunu Ridge, the type section for the caldera-filling Kamaileunu Member of the Waianae Volcanics, Oahu, Hawaii, by John M. Sinton, March 1985. 
Chapter A

\section{Stratigraphic Notes, 1985-86}

Three short papers present changes in stratigraphic nomenclature in Nevada, Hawaii, and Pennsylvania

U.S. GEOLOGICAL SURVEY BULLETIN 1775

CONTRIBUTIONS TO STRATIGRAPHY 


\section{DEPARTMENT OF THE INTERIOR DONALD PAUL HODEL, Secretary \\ U.S. GEOLOGICAL SURVEY \\ Dallas L. Peck, Director}

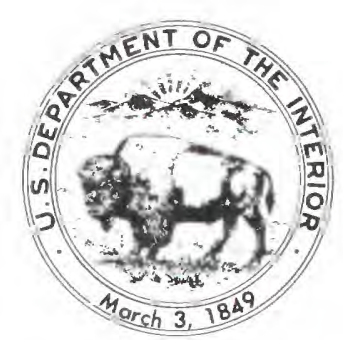

Library of Congress catalog-card No. 86-600372

UNITED STATES GOVERNMENT PRINTING OFFICE: 1987

For sale by the Books and Open-File Reports Section, U.S. Geological Survey, Federal Center, Box 25425, Denver, CO 80225 


\section{CONTENTS}

Stratigraphic nomenclature of volcanic rocks near Manhattan, southern Toquima Range, Nye County, Nevada, by Daniel R. Shawe $\mathbf{A 1}$

Revision of stratigraphic nomenclature of Waianae Volcano, Oahu, Hawaii, by John M. Sinton A9

Regional relations of Upper Silurian-Lower Devonian rocks, Bossardsville, eastern Pennsylvania, by Jack B. Epstein A17 


\title{
Stratigraphic Nomenclature of Volcanic Rocks Near Manhattan, Southern Toquima Range, Nye County, Nevada
}

\author{
By Daniel R. Shawe
}

\begin{abstract}
Volcanic rocks in and near the Manhattan mining district have been miscorrelated with rock units elsewhere in the region; therefore revision of the nomenclature for this area was necessary. Recent K-Ar and fission-track ages for these rocks are older than the ages inferred in earlier reports. The Round Rock, Diamond King, and Bald Mountain Lake Beds Members and the quartz latite member of the Esmeralda Formation in the Manhattan mining district are raised in rank to formational status and called the Round Rock Formation, the Diamond King Formation, the Bald Mountain Formation, and the tuff of Peavine Creek, respectively. As a result, the Esmeralda is geographically restricted from this area. Rocks assigned to the Hedwig Breccia Member of the Esmeralda are renamed the megabreccia of Sloppy Gulch, a unit of the Round Rock Formation, and the name Hedwig Breccia Member is abandoned. These new formations are all of late Oligocene age; the type Esmeralda is Miocene and Pliocene. Rocks mapped as the Maris or Oddie Rhyolite of Miocene age and the informal hornblende and andesite porphyry unit of Pliocene or late Miocene age are designated as parts of the middle member of the Round Rock Formation. Thus the Oddie Rhyolite is restricted from the report area. The Toiyabe Quartz Latite of Miocene age is also restricted from this area; its rocks are now designated the dacite of Ferguson Hill of latest Oligocene age. The Gilbert Andesite of Miocene age is geographically restricted from the report area, and these rocks are now designated the Crone Gulch Andesite (new) of latest Oligocene or earliest Miocene age.
\end{abstract}

\section{INTRODUCTION}

When Ferguson (1924) originally described the volcanic rocks in the Manhattan mining district (fig. 1) and assigned some of them to the Esmeralda Formation and to other units, the rocks were considered to be late Miocene or Pliocene in age. Ferguson (1924, p. 42-43) considered the pyroclastic, igneous, and sedimentary rocks near Manhattan to be equivalent in age to the Siebert Formation, as defined by Ransome (1909, p. 66-68) and by Knopf (1921, p. 150-154). Ferguson's mapping in the region around Tonopah, $55 \mathrm{~km}$ south of Manhattan, convinced him of the similarity of the Siebert with the upper Miocene Esmeralda. Ferguson $(1924$, p. 43) therefore abandoned the name Siebert for rocks that were assigned to the earlier named Esmeralda. The currently adopted age for the Esmeralda Formation is late Miocene to late Pliocene (Robinson and others, 1968). Recent isotopic dating has shown that most of the volcanic rocks in the Manhattan mining district (Shawe and others, 1986) are of latest Oligocene age and are not equivalent in age to the type Esmeralda. Ferguson (1924) and Ferguson and Cathcart (1954) also correlated intrusive rocks in the Manhattan area with the Toiyabe Quartz Latite $30 \mathrm{~km}$ west of Manhattan and with the Gilbert Andesite $65 \mathrm{~km}$ southwest of Manhattan. These latite and andesite rocks are now known to be of different ages, compositions, and (or) volcanic sources and are no longer appropriately correlated with the rocks near Manhattan. Ferguson's (1924) and Ferguson and Cathcart's (1954) stratigraphic nomenclature for the rocks in the Manhattan mining district is therefore herein revised, and some other units that were previously unnamed are herein assigned to named units. Shawe and Snyder (in press) give a more complete discussion of the volcanic rocks near Manhattan in their paper that describes the Manhattan caldera. Detailed distributions of the units discussed here are shown in Shawe (1981a, b) and in Shawe and Snyder (in press).

\section{ROUND ROCK FORMATION}

Ferguson $(1924$, p. $44-46)$ originally assigned the silicic ash-flow tuffs, whose eruption led to the collapse of the Manhattan caldera, to the Round Rock Member of the Esmeralda Formation. However, as the volcanic rocks near Manhattan clearly do not correlate in age with the Esmeralda Formation, the name Esmeralda Formation no longer applies to the volcanic rocks near Manhattan. The Round Rock Member is raised in rank to the Round Rock 


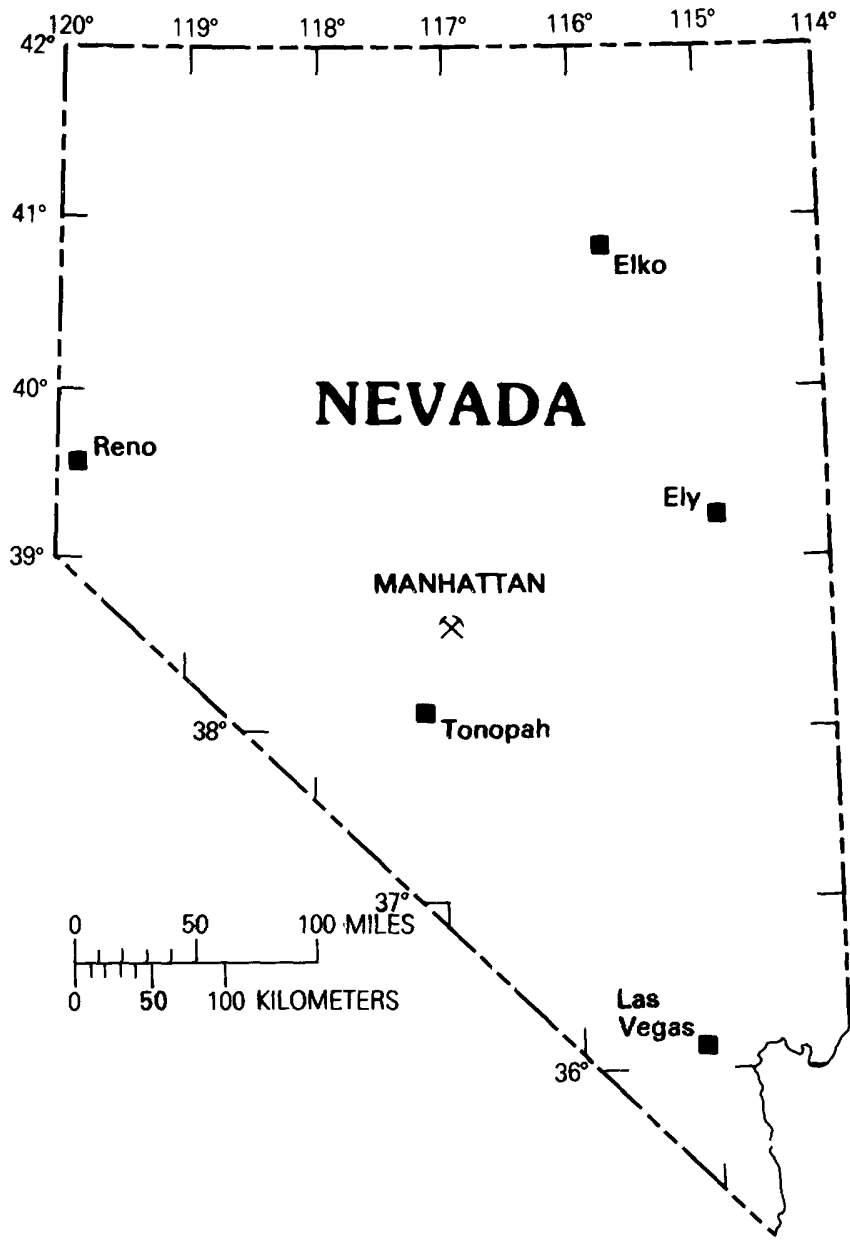

Figure 1. Location of the Manhattan mining district (symbol).

Formation, and its age, which was previously regarded as late Miocene, is now considered to be latest Oligocene on the basis of an approximate 25.0-Ma age (K-Ar method on biotite and fission-track method on zircon) from the unit (Shawe and others, 1986). The contact between the Round Rock Formation and the overlying Diamond King Formation is identical to the contact defined by Ferguson (1924) for his Round Rock and Diamond King Members. The base of the Round Rock Formation is not exposed. The Round Rock Formation near Manhattan is mostly confined to the Manhattan caldera. This distribution suggests that the Round Rock Formation was erupted from the caldera.

Lithic content of the Round Rock Formation is essentially the same as Ferguson (1924) described for his Round Rock Member, except that rocks Ferguson (1924) described as the Maris Rhyolite (now Oddie Rhyolite), as hornblende and biotite andesite porphyry dikes, and as the Hedwig Breccia Member of the Esmeralda Formation are considered in this report to be part of the Round Rock Formation. Also, whereas Ferguson (1924, p. 44-46) recognized that the Round Rock rocks are dominantly pumiceous rhyolite and rhyolitic breccia and tuff, he described some rocks as flows, and he also described subordinate interbedded sandstone layers. I consider the tuffs to be ash-flow tuffs that have minor amounts of interbedded ash-fall tuffs and sedimentary units; I recognized no flow units in the Round Rock Formation.

The Round Rock Formation consists of a lower tuff member that has two associated megabreccia units, a middle member that is itself a megabreccia unit, and an upper tuff member that has two megabreccia units. The lower and upper members are light-colored, poorly consolidated latitic, quartz latitic, and rhyolitic ash-flow and ash-fall tuff layers that are apparently randomly associated and that occur in several cooling units. The lower member probably is at least $1,000 \mathrm{~m}$ thick, and the upper member is $200-300 \mathrm{~m}$ thick. The poorly consolidated ash-flow and ash-fall tuff units of these lower and upper members are characterized by abundant lithic and pumice fragments. Lithic fragments may make up from 1 to nearly 40 percent of the rocks. The tuffs are crystal-poor rocks that contain about 10-27 percent phenocrysts (mostly 1-2 $\mathrm{mm}$ ) consisting of about 50 percent sodic plagioclase and lesser subequal amounts of quartz, sanidine, and mafic minerals. The mafic minerals are mostly biotite, although hornblende is also present in some rocks. Iron-titanium oxide minerals, apatite, and zircon are accessory minerals. The upper and lower members contain relatively thin units of strongly welded ash-flow tuff, vitrophyric ash-flow tuff, air-fall tuff, and volcanic breccia. The compositions of the matrices of the megabreccia units generally are similar to those of the main parts of the upper and lower members.

The middle member of the Round Rock Formation is a megabreccia unit, which consists mostly of fragments, some that are as much as $100 \mathrm{~m}$ in maximum diameter of reddish-brown rhyolite and gray andesite. This rhyolite was previously considered to be a separate formation that Ferguson (1924, p. 50-51) originally named the Maris Rhyolite for outcrops in the vicinity of the Maris Mine 10 km east of Manhattan. Ferguson and Cathcart (1954) abandoned the name Maris Rhyolite and subsequently used the name Oddie Rhyolite, whose type area is the Tonopah district (Spurr, 1905, p. 48-50), for rocks of the Maris Rhyolite in the area around Manhattan. Recent detailed mapping (Shawe and Snyder, in press) shows that the rhyolite is not a separate intrusive unit as Ferguson (1924) had interpreted but is rather part of a layer of rock lying between the upper and lower members, and these rocks are here assigned to the middle member. The age of the Oddie Rhyolite in its type locality is about 16-17 Ma (early-middle Miocene boundary, Bonham and Garside, 1979 , p. 70 ), and the Oddie is clearly not equivalent in age to the middle member of the Round Rock Formation. Because the rhyolite is an integral part of a stratigraphic unit and is more complex than envisaged by Ferguson 
(1924) and by Ferguson and Cathcart (1954), the name Oddie Rhyolite is no longer applicable to the rhyolite in the area around Manhattan, and these rocks are reassigned to the middle member of the Round Rock Formation.

The middle member of the Round Rock Formation is widely distributed as intracaldera facies throughout the Manhattan caldera as a more or less regular, thin layer averaging about $40 \mathrm{~m}$ thick. Lithic material in the megabreccia of the middle member consists of clasts of rhyolite, quartz latite, latite, and andesite, although reddishbrown rhyolite and gray andesite are the most conspicuous rocks seen in outcrops.

The reddish-brown rhyolite clasts in the megabreccia display various breccia fabrics. In some clasts, the rhyolite contains sparse small phenocrysts and appears to be a strongly brecciated flow-layered rhyolite in which are embedded subrounded fragments of crystal-rich structureless rhyolite. In other places, the clasts consist entirely of autobrecciated (?) flow-layered rock without the subround-ed lithic inclusions. In some places, the clasts consist of welded ash-flow tuff having well-defined flattened pumice lapilli that are partly to extensively brecciated.

In the middle member, andesite is a plagioclaserich, generally brecciated rock that contains conspicuous phenocrysts of hornblende and biotite in varied amounts. Ferguson (1924, p. 52-53) described these rocks as hornblende and biotite andesite porphyry dikes that "cut the Round Rock member and apparently also the Maris rhyolite, although no clear proof of this could be found." As was found with the rhyolite, detailed mapping (Shawe and Snyder, in press) shows that the andesite porphyry is not intrusive, as previously interpreted, but rather is part of a layer of rock lying between the upper and lower members, and these andesite rocks are here assigned to the middle member.

Other megabreccia units in the Round Rock Formation are here informally designated the megabreccia of Sloppy Gulch and the megabreccia of Mariposa Canyon, both in the lower member, and the rhyolite megabreccia and the megabreccia of Silver Creek, both in the upper member.

Ferguson $(1924$, p. 43-44) described the megabreccia of Sloppy Gulch, well exposed in Sloppy Gulch just north of Manhattan, as a talus breccia and originally named this megabreccia the Hedwig Breccia Member of the Esmeralda Formation. Ferguson (1924, p. 43-44) described the Hedwig as consisting of talus breccia of small angular fragments of various Paleozoic rocks and granite, but he remarked that none of the materials were mixed. Therefore, he inferred that the materials had a local source even though topographically higher areas of appropriate granite and Paleozoic-rock sources generally are not evident. Apparently he considered that the tuff of the Round Rock Member simply inundated the Hedwig unit after talus deposition. This breccia contains significant exposed tuff and some large-as much as $100 \mathrm{~m}$ long-volcanic clasts imbedded in a tuff matrix that is identical to the ash-flow tuff of the lower member; the breccia is intercalated with intracaldera facies rocks of the lower member about $1 \mathrm{~km}$ north of Manhattan (Shawe and Snyder, in press). The Hedwig Breccia Member is therefore not a separate unit; the name is herein abandoned, and rocks of the unit are reassigned to the megabreccia of Sloppy Gulch.

The megabreccia of Sloppy Gulch is exposed in a broad arc along the south margin of the Manhattan caldera and occurs as intracaldera, vent, and outflow facies deposits. Locally, the megabreccia is at least $200 \mathrm{~m}$ thick and consists of a matrix of volcanic tuff that is identical to the tuff of the lower member and that encloses clasts of brecciated Paleozoic sedimentary and metamorphic rocks, Cretaceous granite, and lesser amounts of rhyolitic tuff. Some of the clasts are blocks as large as 200 by $300 \mathrm{~m}$.

The megabreccia of Mariposa Canyon is also in the lower member and is similar to the megabreccia of Sloppy Gulch. It occurs in a small area along the north margin of the Manhattan caldera about $1 \mathrm{~km}$ north of Mariposa Canyon.

The rhyolite megabreccia occurs as thin intracaldera layers probably no more than $10 \mathrm{~m}$ thick interlayered in the upper member of the Round Rock Formation within the Manhattan caldera near its northeast margin. The megabreccia consists of both brecciated and unbrecciated clasts of rhyolite that are probably no larger than about $5 \mathrm{~m}$ across. The clasts are in tuff matrix similar to the tuff of the upper member.

The megabreccia of Silver Creek covers a large area along the northeast margin of the Manhattan caldera near Silver Creek, where it occurs as intracaldera, vent, and outflow facies deposits in the upper member. Locally, the megabreccia is at least $200 \mathrm{~m}$ thick, and it consists of a matrix of volcanic tuff and pulverized granite that contains generally unbrecciated fragments of mostly granite, some fragments as much as $10 \mathrm{~m}$ in maximum diameter.

\section{DIAMOND KING FORMATION}

Overlying the Round Rock Formation near Manhattan is a unit that Ferguson $(1924$, p. 46-48) named the Diamond King Member of the Esmeralda Formation. Ferguson $(1924$, p. 53-55) also miscorrelated this unit with the late Miocene to late Pliocene Esmeralda Formation near Tonopah. Therefore, $I$ here revise this unit and raise its rank to the Diamond King Formation; its age is now considered to be latest Oligocene (about $25 \mathrm{Ma}$, because the underlying Round Rock is $25.0 \mathrm{Ma}$ and the 
overlying rocks are about $24.6 \mathrm{Ma}$, as determined by the K-Ar method on biotite; Shawe and others, 1986).

The Diamond King Formation is exposed extensively within the Manhattan caldera where the Diamond King is about $150-200 \mathrm{~m}$ thick. The formation probably consists of several ash flows in two or more cooling units. The Diamond King is a light-buff to light-pinkish-brown, generally welded, rhyolitic ash-flow tuff that contains about $25-50$ percent crystals (mostly $1-3 \mathrm{~mm}$ ) predominately of quartz; lesser amounts of sanidine and sodic plagioclase are present. Small amounts of biotite and iron-titanium oxide minerals are present; zircon, apatite, and allanite are accessories. In hand specimen, the Diamond King is characterized by conspicuous smoky quartz dipyramids and by fewer lithic and pumice fragments than occur in the underlying Round Rock Formation. The contact between the Diamond King Formation and the overlying (herein-revised) Bald Mountain Formation is similar to the contact that Ferguson (1924) defined for his Diamond King and Bald Mountain Lake Beds Members. However, I mapped the coarse-grained sedimentary beds that are locally present below fine-grained lake beds of Ferguson's (1924) Bald Mountain Lake Beds Member as part of the Bald Mountain Formation.

Lithic content of the Diamond King Formation is essentially the same content that Ferguson (1924) reported for his Diamond King Member. However, Ferguson $(1924$, p. 46-48) described the lower part of the unit as being dominated by rhyolite flows even though he recognized the presence of tuffs, and he pointed out an abundance of sedimentary layers in the upper part of the unit near Manhattan. Rocks that Ferguson considered to be flows are identified here as welded ash-flow tuffs. A few kilometers north of Manhattan, sedimentary layers are only a minor component of the Diamond King.

I (Shawe, 1977) previously correlated the Diamond King Formation with the ash-flow tuff of Mount Jefferson that is exposed about $20 \mathrm{~km}$ north of Manhattan because of their similar lithology and age equivalence (Kleinhampl and Ziony, 1967; Marvin and others, 1973, p. 4); petrographic studies and new age data now indicate differences that preclude correlation. The source of the Diamond King remains unknown. The Diamond King possibly was derived from a caldera now buried beneath the alluvium of Big Smoky Valley west of Manhattan.

\section{BALD MOUNTAIN FORMATION}

Overlying the Diamond King Formation within the Manhattan caldera are buff-colored claystone and siltstone lake beds and sandstone and conglomerate fluvial deposits. These beds are made of mostly volcanic detritus. Ferguson $(1924$, p. $48-50)$ originally named the unit, which is about $200-250 \mathrm{~m}$ thick, the Bald Mountain Lake
Beds Member of the Esmeralda Formation. The unit is here revised and is raised in rank to the Bald Mountain Formation; its age is now considered to be latest Oligocene (Shawe and others, 1986). Like the Round Rock and Diamond King Formations, the Bald Mountain Formation is no longer regarded as correlative with the younger Esmeralda Formation.

The contact between the Bald Mountain Formation and the overlying tuff of Peavine Creek is identical to the contact that Ferguson (1924) defined between the Bald Mountain Lake Beds Member and quartz latite member.

The lithic content of the Bald Mountain Formation is similar to the content that Ferguson (1924) described to characterize the Bald Mountain Lake Beds Member. However, beyond the area that Ferguson mapped (several kilometers north of Manhattan), I recognized abundant coarse-grained fluvial layers in the unit; some of the layers are as coarse as cobble conglomerate.

\section{TUFF OF PEAVINE CREEK}

The youngest stratigraphic unit in the volcanic succession near Manhattan overlies the Bald Mountain Formation. This unit is here informally designated the tuff of Peavine Creek. It consists of poorly consolidated, lightgreenish-buff and buff, quartz latitic and rhyolitic ash-flow and ash-fall tuff and interlayered, densely welded, lightbrown ash-flow tuff. Ferguson (1924, p. 50) named the unit the quartz latite member of the Esmeralda Formation; revision of this name is based on the latest Oligocene age of the tuff unit, and the tuff can no longer be regarded as correlative with the younger Esmeralda Formation. The tuff of Peavine Creek is about 24.6 Ma (K-Ar method on biotite and fission-track method on zircon; Shawe and others, 1986). In the vicinity of Manhattan, the unit is present only within the Manhattan caldera, where its maximum remnant thickness is about $250 \mathrm{~m}$. The tuff probably was erupted from a caldera, which was mapped by G.F. Brem (Brem and Snyder, 1983; Brem, written commun., June 1983), in the southern Toiyabe Range near Peavine Creek, 20-30 km west-northwest of Manhattan. The poorly consolidated tuffs and the welded tuffs both contain low to moderate amounts of phenocrysts consisting of varied amounts of quartz, sanidine, and sodic plagioclase. Biotite is present in small but locally conspicuous amounts, and it appears to be most abundant in the lower part of the unit. Iron-titanium oxide minerals, apatite, and zircon are accessories.

The tuff of Peavine Creek has the same lithic content as Ferguson (1924) described to characterize his quartz latite member. Although Ferguson (1924, p. 50) recognized the presence of tuffs, he identified the denser units as pumiceous silicic lava rather than as welded ash-flow tuff, a rock type that was not understood 60 years ago. 


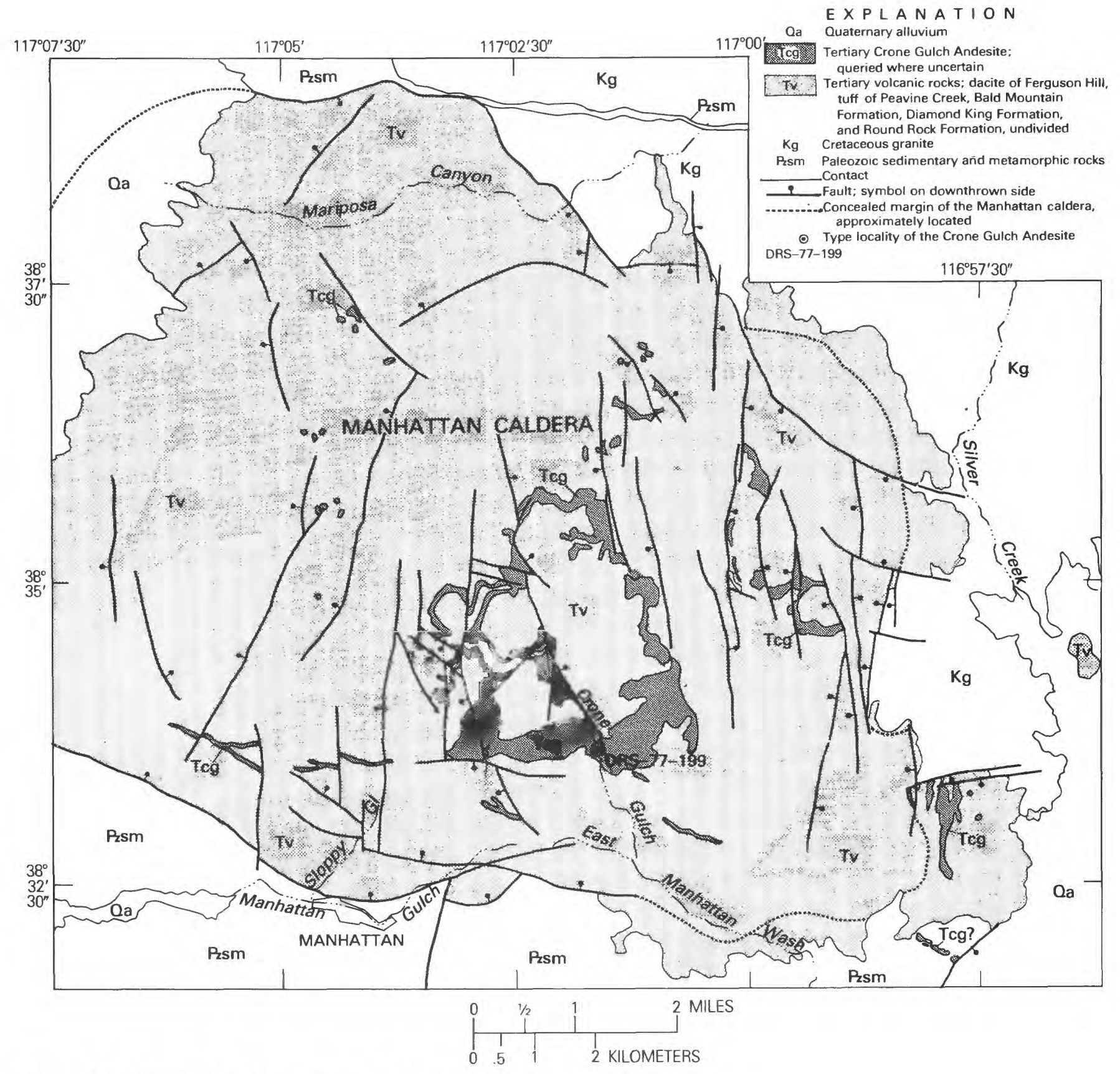

Figure 2. Simplified geologic map of the Manhattan caldera.

\section{DACITE OF FERGUSON HILL}

Two large shallow plugs and satellitic dikes and sills of flow-layered rock, which Ferguson $(1924$, p. 53) identified as dacite, form a low hill $5 \mathrm{~km}$ north-northwest of Manhattan. The unit is here informally named the dacite of Ferguson Hill, a hill named by me to honor the geologic contributions of Henry Gardiner Ferguson (1882-1966) in the Manhattan district (U.S. Board on Geographic Names, 1981, p. 11). Ferguson and Cathcart (1954) assumed that the dacite was an outlier of the Toiyabe
Quartz Latite exposed in the Toiyabe Range about $30 \mathrm{~km}$ west of Manhattan and that the dacite rested unconformably on part of the Esmeralda Formation. They thought that the Toiyabe Quartz Latite in the Manhattan area was lava flows, flow breccias, and tuffs of Pliocene(?) age. However, Stewart and Carlson (1976) indicated that in its type area, the Toiyabe Quartz Latite primarily consists of ash-flow tuffs that belong to the group of volcanic rocks in Nevada that are 34-17 Ma (Oligocene and early Miocene). The dacite of Ferguson Hill differs from the Toiyabe Quartz Latite in composition and in form of 


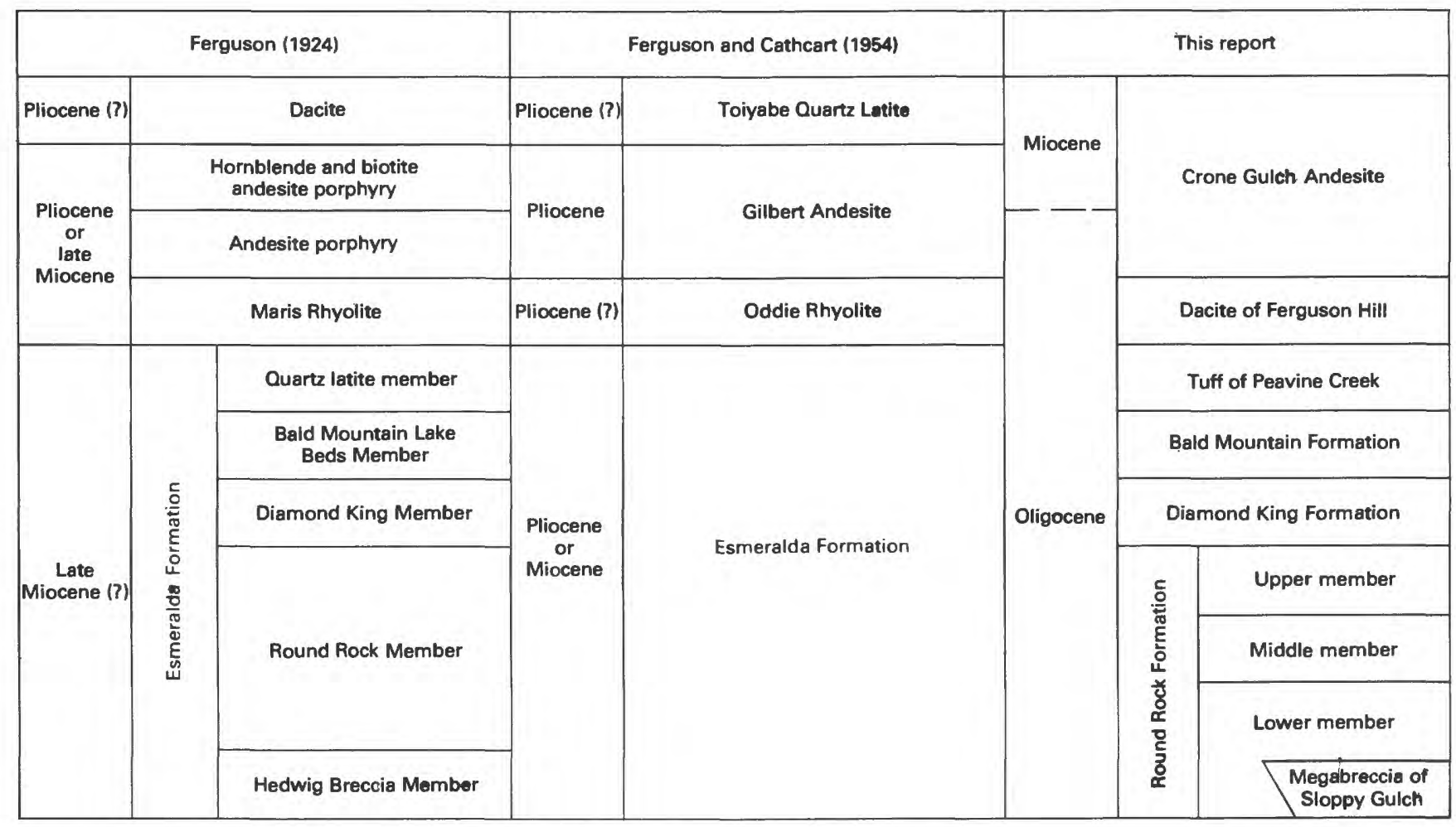

Figure 3. Former and revised nomenclature of volcanic rocks near Manhattan.

occurrence. The Ferguson Hill dacite generally has more calcic plagioclase and less potassium feldspar and occurs as plugs, dikes, and sills rather than as ash flows. The dacite of Ferguson Hill can no longer be regarded as physically correlative with the Toiyabe Quartz Latite, which is here geographically restricted from the report area. The dacite rocks are about $24.5 \mathrm{Ma}$ (K-Ar method on biotite; Shawe and others, 1986). Petrographic studies suggest that these rocks are varied in composition. They are crystal-poor rocks whose phenocryst compositions indicate a range from biotite latite to biotite-quartz latite. About 85 percent of the rock is composed of devitrified glassy matrix. Black vitrophyre layers occur locally.

\section{CRONE GULCH ANDESITE}

Ferguson and Cathcart (1954) assigned the intrusive andesite porphyry north of Manhattan (Ferguson, 1924, p. 51-52) to the Gilbert Andesite whose type locality is the Gilbert district about $65 \mathrm{~km}$ southwest of Manhattan. Ferguson and Cathcart (1954) thought that the age of the so-called Gilbert Andesite in the Manhattan district was Pliocene on the basis of correlation with the Pliocene Gilbert Andesite of the type area (Ferguson, 1928; Ferguson and others, 1953). The currently adopted age of the Gilbert Andesite is Miocene $(15.1 \pm 0.6 \mathrm{Ma}$, K-Ar age; Silberman and McKee, 1972). However, the intrusive andesite north of Manhattan is latest Oligocene or earliest Miocene in age, and it clearly does not correlate in age with the type Gilbert Andesite; also the two andesites were derived from separate volcanic sources. The name Gilbert Andesite therefore is no longer applied to the intrusive andesite north of Manhattan. The intrusive andesite north of Manhattan is here named the Crone Gulch Andesite for exposures in its type locality in Crone Gulch $4 \mathrm{~km}$ northeast of Manhattan (fig. 2; SE $1 / 4 \mathrm{sec}$. 10, T. 8 N., R. 44 E., Manhattan 7.5' quadrangle).

The age of the Crone Gulch Andesite, which was originally considered to be Pliocene, is now considered to be latest Oligocene on the basis of geologic inference (Shawe and Snyder, in press) or earliest Miocene on the basis of an isotopic age of approximately $22 \mathrm{Ma}(\mathrm{K}-\mathrm{Ar}$ method on plagioclase and fission-track method on apatite; Shawe and others, 1986). Evidence exists that the Manhattan caldera was resurgently uplifted because in places where the volcanic units younger than the Round Rock Formation are preserved, the units stand higher in the central part of the caldera than in the marginal parts and outside the caldera. Resurgence is probably the mechanism that elevated the core of the caldera sufficiently to allow gravity sliding of a large mass of volcanic rocks westward to lower terrain within the caldera, where the slide mass is intruded by the 24.5-Ma dacite of Ferguson Hill (Shawe and Snyder, in press). The Crone Gulch Andesite, because of its widespread occurrence 
within the caldera, is probably related to a magma body (shallow pluton?) that caused resurgence of the caldera (Shawe and Snyder, in press). Therefore, in spite of its determined age of about $22 \mathrm{Ma}$, the Crone Gulch is probably not younger than about $24.5 \mathrm{Ma}$.

The Crone Gulch Andesite forms a stock about 3 $\mathrm{km}$ long and $1 \mathrm{~km}$ wide emplaced in the Round Rock and Diamond King Formations 3-5 km northeast of Manhattan. Numerous associated sills were intruded north and northeast of the stock, mostly within the Bald Mountain Formation; a few sills were emplaced in the layered megabreccia of Sloppy Gulch just beyond the southeast corner of the Manhattan caldera. Several west-northwesttrending andesite dikes of composition similar to that of the stock and sills were emplaced in the Round Rock Formation within about $2 \mathrm{~km}$ of the south margin of the caldera, and abundant small plugs intruded mostly the Bald Mountain Formation and the tuff of Peavine Creek in the northwestern half of the caldera (fig. 2). A few irregular sill-like bodies of andesite emplaced in Paleozoic rocks southeast of the Manhattan caldera (fig. 2) may not be related to the Crone Gulch.

The andesite is an olive-brown porphyritic rock that contains about 25 percent labradorite in the form of laths that are as long as $4 \mathrm{~mm}$. The andesite also contains lesser amounts of augite crystals mostly $1 \mathrm{~mm}$ and smaller, set in a finer grained groundmass of plagioclase laths, minor augite, and iron-titanium oxide minerals that are embedded in a devitrified glassy matrix. Apatite is a relatively abundant accessory mineral. Some of the sills contain numerous vesicles filled with chalcedony or calcite.

Chemical compositions of eight samples of the Crone Gulch Andesite are given in Shawe and Lepry (1985). Sample 147 (field sample DRS-77-199) was collected at the type locality of the Crone Gulch (fig. 2). On the basis of these analyses, the Crone Gulch was determined to be a metaluminous alkali-calcic to calcalkalic andesite that has a silica content of 53.2-56.8 percent.

Figure 3 compares the nomenclature formerly applied to the volcanic rocks near Manhattan with the revised names of this report.

\section{REFERENCES CITED}

Brem, G.F., and Snyder, D.B., 1983, Lithology and gravity characteristics of the southern Peavine volcanic center, Toiyabe Range, Nevada: Geological Society of America Abstracts with Program, v. 15, no. 5, p. 280.

Bonham, H.F., Jr., and Garside, L.J., 1979, Geology of the Tonopah, Lone Mountain, Klondike, and northern Mud Lake quadrangles, Nevada: Nevada Bureau of Mines and Geology Bulletin 92, 142 p.

Ferguson, H.G., 1924, Geology and ore deposits of the Manhattan district, Nevada: U.S. Geological Survey Bulletin 723, 163 p.
1928, The Gilbert district, Nevada: U.S. Geological Survey Bulletin 795-F, p. 125-145.

Ferguson, H.G., and Cathcart, S.H., 1954, Geology of the Round Mountain [30-minute] quadrangle, Nevada: U.S. Geological Survey Geologic Quadrangle Map GQ-40, scale 1:125,000.

Ferguson, H.G., Muller, S.W., and Cathcart, S.H., 1953, Geology of the Coaldale quadrangle, Nevada: U.S. Geological Survey Geologic Quadrangle Map GQ-23, scale $1: 125,000$.

Kleinhampl, F.J., and Ziony, J.I., 1967, Preliminary geologic map of northern Nye County, Nevada: U.S. Geological Survey open-file report.

Knopf, Adolf, 1921, The Divide silver district, Nevada: U.S. Geological Survey Bulletin 715-K, p. 147-170.

Marvin, R.F., Mehnert, H.H., and McKee, E.H., 1973, A summary of radiometric ages of Tertiary volcanic rocks in Nevada and eastern California, Part III-Southeastern Nevada: Isochron/West, no. 6, p. 1-30.

Ransome, F.L., 1909, Geology and ore deposits of the Goldfield district, Nevada: U.S. Geological Survey Professional Paper 66, $258 \mathrm{p}$.

Robinson, P.T., McKee, E.H., and Moiola, R.J., 1968, Cenozoic volcanism and sedimentation, Silver Peak region, western Nevada and adjacent California, in Studies in volcanology-A memoir in honor of Howell Williams: Geological Society of America Memoir 116, p. 577-611.

Shawe, D.R., 1977, Preliminary generalized geologic map of the Round Mountain quadrangle, Nye County, Nevada: U.S. Geological Survey Miscellaneous Field Studies Map MF-833, scale 1:24,000.

1981a, Geologic map of the Round Mountain quadrangle, Nye County, Nevada: U.S. Geological Survey OpenFile Report 81-515, scale 1:24,000.

1981b, Geologic map of the Manhattan quadrangle, Nye County, Nevada: U.S. Geological Survey Open-File Report 81-516, scale 1:24,000.

Shawe, D.R., and Lepry, L.B., Jr., 1985, Analytical data for rock samples from the Round Mountain and Manhattan quadrangles, Nye County, Nevada: U.S. Geological Survey Open-File Report 85-0538, 38 p.

Shawe, D.R., Marvin, R.F., Andriessen, P.A.M., Mehnert, H.H., and Merritt, V.M., 1986, Ages of igneous and hydrothermal events in the Round Mountain and Manhattan gold districts, Nye County, Nevada: Economic Geology, v. 81 , p. $388-407$.

Shawe, D.R., and Snyder, D.B., in press, Ash-flow eruptive megabreccias of the Manhattan and Mount Jefferson calderas, Nye County, Nevada: U.S. Geological Survey Professional Paper 1471.

Silberman, M.L., and McKee, E.H., 1972, A summary of radiometric age determinations on Tertiary volcanic rocks from Nevada and eastern California: Part II, western Nevada: Isochron/West, no. 4, p. 7-28.

Spurr, J.E., 1905, Geology of the Tonopah mining district, Nevada: U.S. Geological Survey Professional Paper 42, 295 p.

Stewart, J.H., and Carlson, J.E., 1976, Cenozoic rocks of Nevada: Nevada Bureau of Mines and Geology Map 52, scale $1: 1,000,000$. 
U.S. Board on Geographic Names, 1981, Decisions on geographic names in the United States, July through Septem- ber 1981: U.S. Board on Geographic Names Decision List no. $8103,20 \mathrm{p}$. 


\title{
Revision of Stratigraphic Nomenclature of Waianae Volcano, Oahu, Hawaii
}

\author{
By John M. Sinton ${ }^{1}$
}

\begin{abstract}
The stratigraphic nomenclature for Waianae Volcano, Island of Oahu, Hawaii, is here revised on the basis of field mapping and geochronological and petrologic studies. The Waianae Volcanic Series, as used by Stearns in 1946, is renamed the Waianae Volcanics. It consists of tholeiitic basalt grading upward to alkalic basalt, hawaiite, rare mugearite, and minor ash beds. The Waianae Volcanics is formally subdivided into the Lualualei (oldest), Kamaileunu, and Palehua (youngest) Members (all new), which represent the shield-building, transitional or late-shield, and post-caldera stages of volcanic activity, respectively. An unusual occurrence of rhyodacite in the Mauna Kuwale area, formerly called the Mauna Kusale Trachyte by McDougall in 1963, is here considered to be part of the Kamaileunu Member and is renamed the Mauna Kuwale Rhyodacite Flow. The Waianae Volcanics is unconformably overlain by the Kolekole Volcanics. Certain cones and flows previously considered to be part of the Waianae at the south end of the Waianae Range are assigned to the Kolekole Volcanics.
\end{abstract}

\section{INTRODUCTION}

The Island of Oahu, Hawaii, consists of two coalesced volcanoes-Waianae (west), which is the older of the two, and Koolau (east); the Waianae Range and Koolau Range, respectively, are the highly dissected remnants of these volcanoes (fig. 1). In a comprehensive field study, H.T. Stearns $(1935,1939)$ mapped and described the lithologic and structural relations of Waianae Volcano and defined the Waianae Volcanic Series, which consisted of all the lava flows, intrusive and pyroclastic rocks, and intercalated breccia and soil of Waianae Volcano. He subdivided the Waianae Volcanic Series into three informal units - the lower, middle, and upper members. In addition, he included "trachyte" (now known to be rhyodacite) in the Mauna Kuwale area within the lower member and suggested that the "trachyte" might repre-

\footnotetext{
${ }^{1}$ Hawaii Institute of Geophysics, University of Hawaii, Honolulu, HI 96822.
}

sent an older volcano. Macdonald (1940), however, considered the "trachyte" to be part of the upper member. Posterosional lava found above an erosional unconformity near the top of the upper member of the Waianae by Stearns (1939, 1940) and Macdonald (1940) was later excluded from the Waianae and named the Kolekole Volcanics by Stearns (1946) (see also Macdonald and Davis, in Avias and others, 1956).

More recent work, including field mapping and geochronological and petrologic studies, has clarified many of the stratigraphic relations and lithologic correlations within the volcano and has indicated a need for revision of the stratigraphic nomenclature for Waianae Volcano. The following revisions to Waianae stratigraphic nomenclature are here proposed:

1. The Waianae Volcanic Series as used by Stearns (1946), which is of formational rank, is renamed the Waianae Volcanics to be consistent with the recommendations of the North American Stratigraphic Code (North American Commission on Stratigraphic Nomenclature, 1983).

2. The Waianae Volcanics is formally subdivided into the Lualualei Member (oldest), Kamaileunu Member, and Palehụa Member (youngest) (all new).

3. The Kamaileunu Member includes a formally named flow-the Mauna Kuwale Rhyodacite Flow.

4. The Kolekole Volcanics, which is also of formational rank, is geographically extended to include certain cones and flows previously included in the upper member of the Waianae Volcanic Series by Stearns $(1935,1939,1940,1946)$ and Macdonald (1940).

These revisions are documented below. The K-Ar ages discussed in this paper are those reported in the original publications and have not been recalculated by using the new decay constants.

\section{Acknowledgments}

This paper is dedicated to the memory of the late Harold T. Stearns who set the standard for geologic mapping in Hawaii and throughout the Pacific Basin. I am 


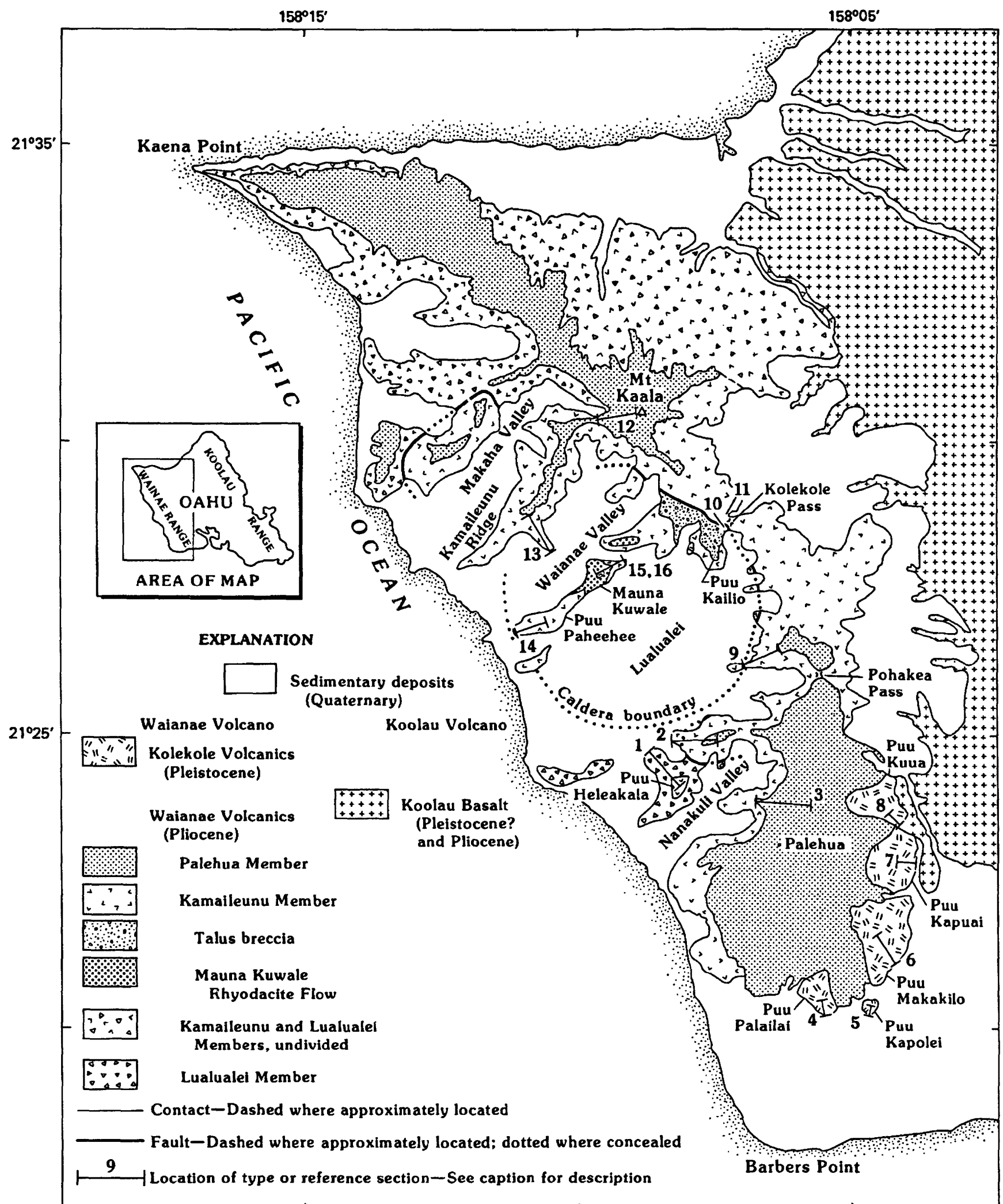

0 KILOMETERS 
Figure 1. Geologic map of the western part of the Island of Oahu, showing type and reference sections for the members of the Waianae Volcanics and for the Kolekole Volcanics of Waianae Volcano. 1, Lualualei Member, type section; 2, Kamaileunu Member, reference section; 3, Palehua Member, type section; 4-8, Kolekole Volcanics, reference sections; 9, Kamaileunu Member, reference section; 10, Kolekole Volcanics, type section; 11, Kolekole Volcanics, reference section; 12, Palehua Member, reference section; 13, Kamaileunu Member, type section; 14, Kamaileunu Member, reference section; 15, Kamaileunu Member, reference section; 16, Mauna Kuwale Rhyodacite Flow, type section. Dikes and minor faults not shown. Outcrops of the Kolekole Volcanics near Kolekole Pass too small to show. Geology by J.M. Sinton (1978-86) after Stearns (1939) and Macdonald (1940).

grateful to Virginia Langenheim, without whose persuasive encouragement this paper would never have been written. Reviews by David Clague, Jim Moore, Virginia Langenheim, Ralph Moberly, and Frank Peterson significantly improved the manuscript. R.C. Price of La Trobe University, JoAnn Sinton, and Elizabeth Zbinden helped obtain some of the chemical data reported here. Some of the field work in the Waianae Range was supported by DOE/DGE Contract EW-78-S-07-1713. This is Hawaii Institute of Geophysics Contribution number 1789.

\section{WAIANAE VOLCANICS}

The Waianae Volcanics comprises all the lava flows, intrusive and pyroclastic rocks, and closely associated sedimentary rocks of Waianae Volcano not included in the Kolekole Volcanics (see section Kolekole Volcanics). Its total exposed thickness is about $2,000 \mathrm{~m}$, and it consists mainly of tholeiitic basalt in the lowest exposed sections, grading upward to alkalic basalt, hawaiite, and rare mugearite lava flows and minor ash beds. The Waianae Volcanics is exposed throughout the Waianae Range of western Oahu, Hawaii. The base of the unit is not exposed, but presumably it extends below sea level to the ocean floor. The Waianae is overlain unconformably by the Kolekole Volcanics, also of Waianae Volcano, and by the Koolau Basalt (Langenheim and Clague, 1987) of Koolau Volcano. The age of the Waianae Volcanics ranges from 3.8 to 2.4 Ma (McDougall, 1964; Funkhouser and others, 1968; Doell and Dalrymple, 1973). The Waianae Volcanics, which includes lavas having both normal and reversed magnetic polarities, was erupted during the Gilbert Reversed and Gauss Normal Polarity Chrons (Doell and Dalrymple, 1973).

The Waianae Volcanics is subdivided into the Lualualei (oldest), Kamaileunu, and Palehua (youngest) Members.

\section{Lualualei Member (New)}

The Lualualei Member is here named for exposures surrounding the valley of Lualualei (fig. 1). The Lualualei Member, which includes the oldest exposed rocks of the Waianae Volcanics, consists exclusively of shield-building stage tholeiitic basalt with minor intercalated ash beds.
Aphyric and olivine-phyric basalts are the dominant lithology. The flows dip away from the caldera boundary of Waianae Volcano.

The type section for the Lualualei Member is the section exposed at Puu Heleakala (figs. 1, 2); this section has been studied in detail by Macdonald and Katsura (1964) and Doell and Dalrymple (1973). The lower contact of the Lualualei Member is not exposed. At the type section, the Lualualei grades upward into the Kamaileunu Member; the contact between them is arbitrarily placed at the lowest clinopyroxene-saturated lava in the section (fig. 2). The Lualualei is in fault contact with the overlying Kamaileunu Member north-northeast of Puu Heleakala (fig. 1). The Lualualei Member has fewer plagioclase-phyric lava flows and fewer ash beds than the Kamaileunu Member and is composed exclusively of tholeiitic basalt; pyroxene-saturated lithologies are rare. The Lualualei Member includes part of the lower member and the lowermost part of the middle member of the Waianae Volcanic Series as used by Stearns $(1935,1939)$.

At this writing, revised mapping of the Waianae Range is continuing, and much of the Lualualei Member has yet to be differentiated from the Kamaileunu Member described below. However, the Lualualei Member is known to occur on the south side of Lualualei valley where the exposed section has a minimum thickness of $450 \mathrm{~m}$. It is present in drill cores from Lualualei valley to at least $400 \mathrm{~m}$ below sea level.

$\mathrm{K}$-Ar dated flows of the Lualualei Member range in age from 3.8 to $3.0 \mathrm{Ma}$ (McDougall, 1964; Doell and Dalrymple, 1973). The type section has an average K-Ar age of 3.62 $\pm 0.11 \mathrm{Ma}$ (Doell and Dalrymple, 1973).

\section{Kamaileunu Member (New)}

The Kamaileunu Member is here named for exposures on Kamaileunu Ridge (fig. 1). The Kamaileunu Member represents a transitional or late-shield stage of volcanic activity. During this period, lavas progressively filled a caldera, and compositions became more alkalic. Lava flows in the lower part of the Kamaileunu Member are composed of olivine- and (or) plagioclase-phyric tholeiitic basalt having slightly higher $\mathrm{TiO}_{2}, \mathrm{~K}_{2} \mathrm{O}, \mathrm{Sr}, \mathrm{Zr}$, and $\mathrm{Ba}$ contents than the tholeiitic basalt of the Lualualei Member (table 1). Upsection, the Kamaileunu has increas- 


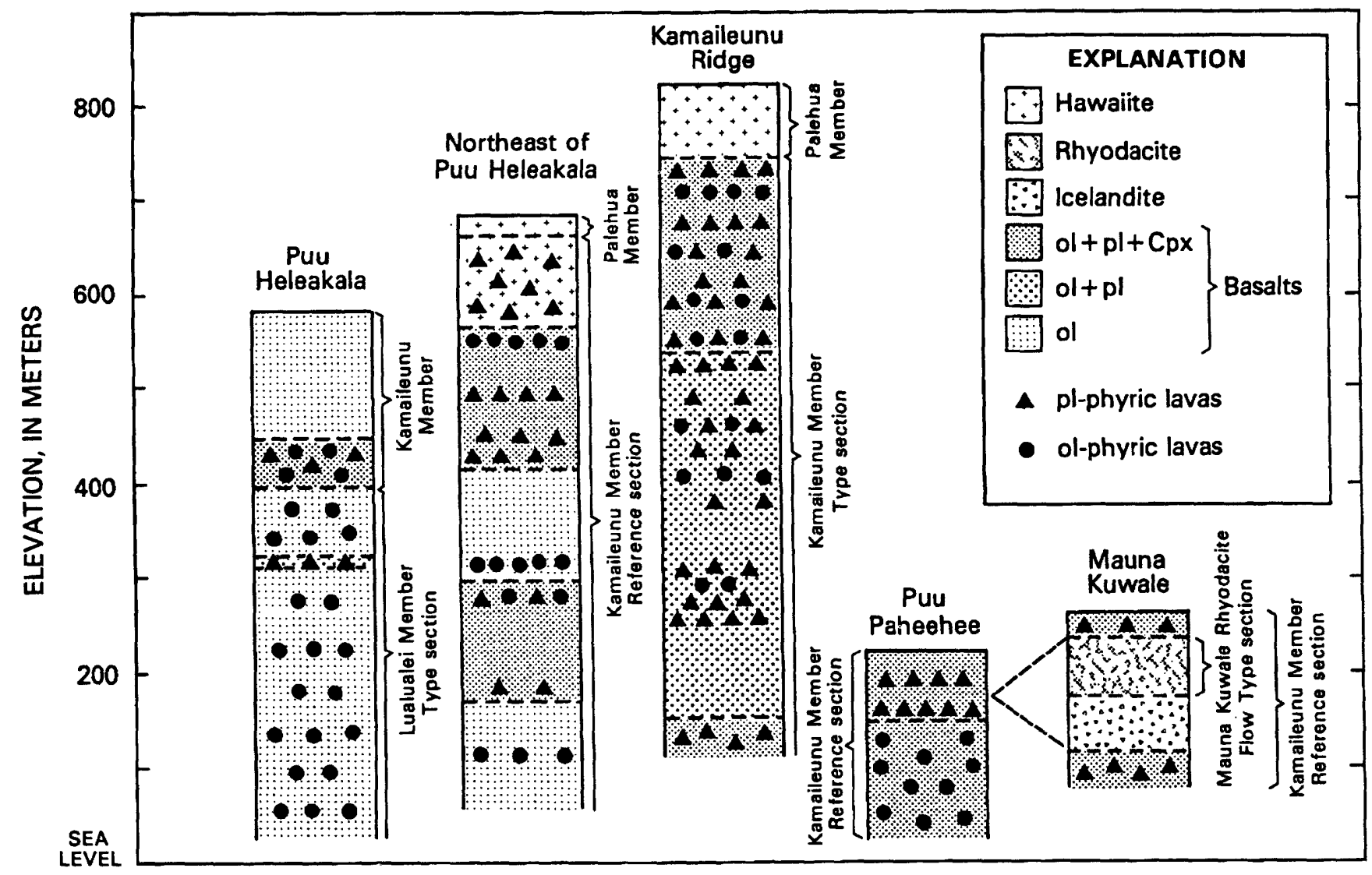

Figure 2. Type and reference sections of the Lualualei and Kamaileunu Members of the Waianae Volcanics. Locations shown on figure 1. Basalts have been separated according to their near-liquidus phases as determined by petrographic analysis; porphyritic horizons are shown by phenocryst type (ol, olivine; pl, plagioclase; Cpx, clinopyroxene). Phenocryst abundances in phyric lavas are proportional to density of symbols shown for those lavas. The bases of the sections are not exposed.

ing proportions of alkalic lithologies that include olivinephyric and plagioclase-phyric alkalic basalt, hawaiite, and rare ankaramite. Ash beds and soil horizons are increasingly common upsection and indicate a general decrease in eruption frequency and a general increase in explosivity of eruptions during this interval. The Kamaileunu Member includes several intracaldera icelandite flows and tuff

Table 1. Some chemical characteristics of lava flows of the Waianae Volcanics

[All analyses by X-ray fluorescence at Hawaii Institute of Geophysics. Oxide values in weight percent; trace element values in parts per million]

\begin{tabular}{lcccc}
\hline & $\begin{array}{c}\text { Lualualei } \\
\text { Member }\end{array}$ & $\begin{array}{c}\text { Kamaileunu } \\
\text { Member }^{4}\end{array}$ & \multicolumn{2}{c}{ Palehua Member } \\
\cline { 4 - 5 } & Hawaiite & Mugearite \\
\hline $\mathrm{TiO}_{2} \ldots \ldots$ & $1.9-2.8$ & $2.3-3.4$ & $3.2-4.4$ & $2.2-2.6$ \\
$\mathrm{~K}_{2} \mathrm{O} \ldots \ldots$ & $.2-0.5$ & $.5-0.7$ & $.55-1.6$ & $2.1-2.5$ \\
$\mathrm{P}_{2} \mathrm{O}_{5} \ldots \ldots$ & $.2-0.5$ & $.3-0.5$ & $.5-0.8$ & $1.1-1.5$ \\
$\mathrm{Sr} \ldots \ldots$ & $300-470$ & $440-590$ & $490-820$ & $790-900$ \\
$\mathrm{Zr} \ldots \ldots$ & $130-190$ & $155-275$ & $240-400$ & $460-610$ \\
$\mathrm{Ba} \ldots \ldots$ & $70-102$ & $130-230$ & $150-480$ & $640-690$ \\
\hline
\end{tabular}

${ }^{1}$ Excluding silicic rocks (icelandite and rhyodacite). and one rhyodacite lava flow (see section Mauna Kuwale Rhyodacite Flow). Several occurrences of talus breccia (fig. 1) are also tentatively included in the Kamaileunu because the breccia appears to be closely associated with Kamaileunu flows.

The lower contact of the Kamaileunu Member with the Lualualei Member is generally conformable, although locally the Kamaileunu is in fault contact with the Lualualei. In most places, the Kamaileunu is conformably overlain by hawaiite of the Palehua Member. At Pohakea Pass (fig. 1), this contact is unconformable, and aphyric hawaiite of the Palehua overlies weathered plagioclasephyric basalt and hawaiite topped by a few centimeters of red, ashy soil of the Kamaileunu Member.

All of the lithologies of the Kamaileunu Member are not exposed in any single section. The section on Kamaileunu Ridge, between Waianae and Makaha Valleys, is an easily accessible, nearly complete section about $615 \mathrm{~m}$ thick (figs. 1, 2). Here the Kamaileunu is overlain conformably by Palehua hawaiite at the 788-m (2,560-ft) elevation. This section of the Kamaileunu is designated 
the type section. Reference sections for the Kamaileunu are designated as the sections northeast of Puu Heleakala (Macdonald and Katsura, 1964; Doell and Dalrymple, 1973), between the caldera boundary fault and the Palehua Member north of Pohakea Pass, at Puu Paheehee, and at Mauna Kuwale. The Mauna Kuwale section shows the silicic lava flows and their contacts with the underlying and overlying flows (figs. 1,2). At the reference section at Mauna Kuwale, Kamaileunu transitional alkalic basalt is overlain in turn by $1 \mathrm{~m}$ of icelandite airfall ash, about 59 $\mathrm{m}$ of icelandite block lava, $62 \mathrm{~m}$ of rhyodacite lava (Mauna Kuwale Rhyodacite Flow), a few centimeters of red soil, and finally $29 \mathrm{~m}$ of plagioclase-phyric basalt (or basaltic hawaiite) (fig. 2).

The previously dated rocks from the Waianae Range (McDougall, 1964; Funkhouser and others, 1968; Doell and Dalrymple, 1973) that are unequivocally within the Kamaileunu Member, as defined here, span ages from 3.46-2.95 Ma. The reference section northeast of Puu Heleakala studied by Macdonald and Katsura (1964) was $\mathrm{K}$-Ar dated at $3.00 \pm 0.38 \mathrm{Ma}$ by Doell and Dalrymple (1973).

\section{Mauna Kuwale Rhyodacite Flow}

The unusual flow in the Mauna Kuwale area, now known to be a rhyodacite (Macdonald and Katsura, 1964), was previously considered to be a trachyte by some authors and was included in different members of the Waianae: lower member (Stearns, 1935, 1939); middle member (Stearns, 1946; Macdonald, 1949); and upper member (Macdonald, 1940). McDougall $(1963,1964)$, on the basis of the much older K-Ar age he obtained for the flow in the Mauna Kuwale area (8.4 Ma) than for other Waianae flows (3.3-2.9 Ma), did not consider the flow in the Mauna Kuwale area to be part of the Waianae, but rather a separate unit that he called Mauna Kuwale Trachyte. Funkhouser and others $(1966,1968)$, however, placed the flow, which they called the Mauna Kuwale Rhyodacite, in the upper member of the Waianae, concluding that the flow was more nearly $2-3 \mathrm{Ma}$ and that McDougall's $\mathrm{K}$-Ar age ( $8.4 \mathrm{Ma})$ might be caused by excess argon retention in the glassy lava.

The flow is a highly distinctive glassy, hornblendebiotite-hypersthene rhyodacite, a unique lithology unknown elsewhere in the Hawaiian Islands. Because the flow is of such a distinct lithology, it is considered to be a formally named flow, here called the Mauna Kuwale Rhyodacite Flow, and is assigned to the Kamaileunu Member on the basis of its stratigraphic relations. The Mauna Kuwale Rhyodacite Flow is present at Manna Kuwale and on the ridge immediately northeast of Mauna Kuwale (fig. 1). At its type section (here designated) (fig. 2), the flow is about $62 \mathrm{~m}$ thick; elsewhere at Mauna Kuwale, it ranges from $45-111 \mathrm{~m}$ thick. On the ridge immediately northeast of Mauna Kuwale, the flow ranges from 15 to $30 \mathrm{~m}$ thick (Bauer and others, 1973) (figs. 1, 2).

Although Funkhouser and others (1968) reported an age of $2.33 \pm 0.11 \mathrm{Ma}$ (average of 11 determinations) for this flow, that age is inconsistent with the ages they reported for dikes cutting it (3.2-3.0 Ma) and for the overlying lava flow (4.3 $\pm 1.1 \mathrm{Ma})$. Thus, the age of the Mauna Kuwale Rhyodacite Flow is still in question, but a minimum age of $3.2 \mathrm{Ma}$ is consistent with the other data.

\section{Palehua Member (New)}

The Palehua Member, here named for extensive exposures around the settlement of Palehua at the south end of the Waianae Range (fig. 1), is equivalent to the upper member of the Waianae Volcanic Series of Stearns $(1935,1939)$ and Macdonald (1940), excluding the lavas here considered to be part of the Kolekole Volcanics. The Palehua Member is exposed along the higher elevations throughout the Waianae Range and represents the postcaldera-stage eruptive products of the Waianae Volcanics. The dominant lithology is hawaiite, although minor alkalic basalt and mugearite locally occur. The Palehua Member is generally conformable over the Kamaileunu Member; locally, as at Pohakea Pass, the Palehua unconformably overlies the Kamaileunu. The maximum thickness of the Palehua Member, slightly more than $300 \mathrm{~m}$, is near Mount Kaala. A more accessible, although somewhat thinner (about $200 \mathrm{~m}$ thick), sequence near Palehua is designated the type section; the section near Mount Kaala is designated a reference section (fig. 1).

Reported K-Ar ages for unequivocal Palehua Member lava range from 2.95-2.4 Ma (McDougall, 1964; Funkhouser and others, 1968; Doell and Dalrymple, 1973). A massive Palehua hawaiite flow in the northern part of the Waianae Range, having reversed magnetic polarity that led to.the discovery of the Kaena Reversed Polarity Subchron within the Gauss Normal Polarity Chron, has been dated at $2.85 \pm 0.05 \mathrm{Ma}$ (Doell and Dalrymple, 1973).

\section{KOLEKOLE VOLCANICS}

Stearns $(1939$, p. 3,$10 ; 1940$, p. 47-48) described the occurrence of a posterosional lava flow in his Waianae Volcanic Series near Kolekole Pass, and both he and Macdonald (1940, p. 88) speculated as to the relations between this flow and the young cones and flows at the south end of the Waianae Range that they also included in the Waianae. The young cones and flows were called the "Laeloa Craters" by Hitchcock (1900, p. 37). Stearns (1946) excluded the flow near Kolekole Pass from the Waianae and named it the Kolekole Volcanics. Macdonald and Davis (in Avias and others, 1956) designated the type 
locality as Kolekole Pass. However, there are two separate exposures in the Kolekole Pass area: a 2-m-thick flow 0.18 $\mathrm{km}$ west of the pass, here designated the type section, and associated cinder deposits lying on alluvium $0.8 \mathrm{~km}$ north of Kolekole Pass, here designated a reference section.

The Kolekole lava was described as olivine basalt by Macdonald (1940). The flow has subsequently been chemically analyzed (table 2) and found to be mafic alkalic lava having normative andesine. It is similar in composition to lava from three analyzed "Laeloa" flows (table 2, samples $2,3,4)$ previously included in the upper member (Palehua) of the Waianae by Macdonald (1940). Although the Kolekole and "Laeloa" lavas share some characteristics with hawaiite of the Palehua Member, such as normative andesine and feldspar-rich trachytic groundmass textures, the former are richer in olivine, have higher $\mathrm{MgO}, \mathrm{Sc}, \mathrm{Cr}$, $\mathrm{Ni}, \mathrm{Rb}$, and $\mathrm{Sr}$, and have lower $\mathrm{SiO}_{2}, \mathrm{TiO}_{2}, \mathrm{Y}$, and $\mathrm{Zr}$ (table 2). Thus, currently available data confirm the

Table 2. Chemical composition of lava of the Kolekole Volcanics compared to hawaiite of the Palehua Member of the Waianae Volcanics

[All analyses by X-ray fluorescence at Hawaii Institute of Geophysics. 1. Posterosional mafic alkalic lava flow, $0.2 \mathrm{~km}$ west of Kolekole Pass. 2. Mafic alkalic lava flow from Puu Makakilo, roadcut north side of Highway H1, $1.3 \mathrm{~km}$ northwest of junction with Highway 901. 3. Mafic alkalic lava flow from Puu Palailai, quarry $0.4 \mathrm{~km}$ northwest of junction of Highway $\mathrm{H} 1$ and Kalaeloa Boulevard. 4. Xenolith-bearing mafic alkalic lava from Puu Kapolei, Highway $9010.6 \mathrm{~km}$ south-southeast of junction with Highway H1. 5. Average of 13 Palehua hawaiite flows; trace-element data are average of 11 of these. $\mathrm{Fe}_{2} \mathrm{O}_{3}$ was not analyzed directly in these samples and is here shown with $\mathrm{Fe}_{2} \mathrm{O}_{9} /$ total $\mathrm{Fe}$ as $\mathrm{FeO}$ $=0.22]$

\begin{tabular}{|c|c|c|c|c|c|}
\hline & \multicolumn{4}{|c|}{ Kolekole Volcanics } & \multirow{2}{*}{$\begin{array}{c}\begin{array}{c}\text { Palehua Member } \\
\text { (average hawaiite) }\end{array} \\
5\end{array}$} \\
\hline & 1 & 2 & 3 & 4 & \\
\hline \multicolumn{6}{|c|}{ Oxides (weight percent) } \\
\hline 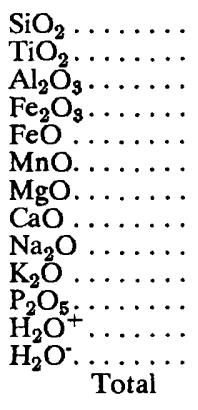 & $\begin{array}{r}45.86 \\
2.92 \\
13.24 \\
4.76 \\
7.87 \\
.18 \\
9.96 \\
9.16 \\
3.06 \\
1.04 \\
.51 \\
.76 \\
.30 \\
99.62\end{array}$ & $\begin{array}{r}46.09 \\
3.24 \\
13.50 \\
6.71 \\
6.52 \\
.16 \\
8.61 \\
9.08 \\
3.34 \\
.98 \\
.57 \\
1.40 \\
.60 \\
100.80\end{array}$ & $\begin{array}{r}46.38 \\
3.15 \\
14.37 \\
6.73 \\
6.15 \\
.19 \\
7.56 \\
8.81 \\
2.98 \\
1.22 \\
.72 \\
.93 \\
.49 \\
99.68\end{array}$ & $\begin{array}{r}45.93 \\
2.89 \\
12.79 \\
5.42 \\
7.97 \\
.18 \\
9.95 \\
8.79 \\
2.88 \\
.97 \\
.56 \\
1.29 \\
.22 \\
99.84\end{array}$ & $\begin{array}{r}49.63 \\
3.82 \\
13.47 \\
2.68 \\
9.65 \\
.18 \\
4.73 \\
8.86 \\
3.08 \\
.91 \\
.69 \\
.89 \\
.68 \\
99.27\end{array}$ \\
\hline \multicolumn{6}{|c|}{ Trace elements (parts per million) } \\
\hline $\begin{array}{l}\mathrm{Sc} \\
\mathrm{Cr} \\
\mathrm{Ni} \\
\mathrm{Cu} \\
\mathrm{Zn} \\
\mathrm{Rb} \\
\mathrm{Sr} \\
\mathrm{Y} \\
\mathrm{Zr} \\
\mathrm{Nb}\end{array}$ & $\begin{array}{r}26 \\
450 \\
356 \\
53 \\
171 \\
18 \\
671 \\
-183 \\
18-\end{array}$ & $\begin{array}{r}27 \\
301 \\
300 \\
63 \\
120 \\
15 \\
739 \\
29 \\
209 \\
24\end{array}$ & $\begin{array}{r}27 \\
263 \\
223 \\
64 \\
112 \\
22 \\
885 \\
27 \\
255 \\
29\end{array}$ & $\begin{array}{r}26 \\
470 \\
1035 \\
485 \\
110 \\
17 \\
689 \\
32 \\
199 \\
24\end{array}$ & $\begin{array}{r}22 \\
52 \\
65 \\
76 \\
129 \\
12 \\
574 \\
47 \\
315 \\
20\end{array}$ \\
\hline
\end{tabular}

suspicions of Stearns and Macdonald that the Kolekole flow and the youngest eruptive products at the south end of the range might represent a common lithologic unit. Hence, the name Kolekole Volcanics is here geographically extended to include the young cones and flows on the south end of the range and other occurrences as shown on figure 1. Reference sections are here designated at the south end of the Waianae Range at Puu Kuua, Puu Kapuai, Puu Makakilo, Puu Kapolei, and Puu Palailai (fig. 1). In each of these localities, Kolekole lavas are characterized by the presence of discrete xenoliths, mainly of dunite, but locally, as at Puu Kapolei, by a diverse suite of clinopyroxene-dominated xenocrysts and cumulate xenoliths.

The total distribution and maximum thickness of the Kolekole Volcanics are presently unknown. The unit is clearly unconformable on older Kamaileunu lavas and alluvium at Kolekole Pass, but stratigraphic relations at the south end of the Waianae Range are less clear. The presence of dunite xenoliths near the summit of Mount Kaala (Macdonald, 1940, p. 80) suggests that Kolekole lava may also be present there. A posterosional cinder cone on the northeast side of Lualualei valley about 1.8 $\mathrm{km}$ southwest of Kolekole Pass has been tentatively assigned to this unit (fig. 1). The Kolekole is overlain by the Koolau Basalt near Puu Kuua and in drill holes on the southeast side of the Waianae Range.

Although the Kolekole Volcanics is younger than the Waianae Volcanics, the isotopic age of the Kolekole is not known. The Kolekole is here tentatively considered to be Pleistocene. Stearns (1946) assigned a Pleistocene age to the unit and suggested that it might be correlative with the Honolulu Volcanics (formerly the Honolulu Volcanic Series) of Koolau Volcano. However, the rocks that have so far been assigned to the Kolekole are lithologically distinct from those of the Honolulu, and, because the Kolekole has not been isotopically dated, it is unknown if the two units are about the same age.

\section{REFERENCES CITED}

Avias, Jacques, Davis, D.A., Hanzala, F., Ladd, H.S., Macdonald, G.A., and Obellianne, J.M., 1956, Oceanie proprement dite, Pt. 2, Oceanie, v. 6 of Lexique Stratigraphique International: Paris, Centre National de la Recherche Scientifique, $286 \mathrm{p}$.

Bauer, G.R., Fodor, R.V., Hustler, J.W., and Keil, Kiel, 1973, Contributions to the mineral chemistry of Hawaiian rocks, pt. III, Composition and mineralogy of a new rhyodacite occurrence on Oahu, Hawaii: Contributions to Mineralogy and Petrology, v. 40, p. 183-194.

Doell, R.R., and Dalrymple, G.B., 1973, Potassium-argon ages and paleomagnetism of the Waianae and Koolau Volcanic Series, Oahu, Hawaii: Geological Society of America Bulletin, v. 84 , p. $1217-1242$. 
Funkhouser, J.G., Barnes, I.L., and Naughton, J.J., 1966, Problems in the dating of volcanic rocks by the potassiumargon method: Bulletin Volcanologique, v. 29, p. 709-718. 1968, The determination of a series of ages of Hawaiian volcanoes by the potassium-argon method: Pacific Science, v. 22, p. 369-372.

Hitchcock, C.H., 1900, Geology of Oahu: Geological Society of America Bulletin, v. 11, p. 15-57.

Langenheim, V.A., and Claque, D.A., 1987, The HawaiianEmperor volcanic chain; pt. II, Stratigraphic framework of volcanic rocks of the Hawaiian Islands, in Decker, R.W., Wright, T.L., and Stauffer, P.H., eds., Volcanism in Hawaii: U.S. Geological Survey Professional Paper 1350, p. 55-84.

Macdonald, G.A., 1940, Petrography of the Waianae Range, Oahu, in Stearns, H.T., Supplement to geology and ground-water resources of the Island of Oahu, Hawaii: Hawaii Division of Hydrography, Bulletin 5, p. 61-91.

-1949, Hawaiian petrographic province: Geological Society of America Bulletin, v. 60, p. 1541-1596.
Macdonald, G.A., and Katsura, T., 1964, Chemical composition of Hawaiian lavas: Journal of Petrology, v. 5, p. 82-133.

McDougall, Ian, 1963, Potassium-argon ages from western Oahu, Hawaii: Nature, v. 197, no. 4865, p. 344-345.

1964, Potassium-argon ages from lavas of the Hawaiian Islands: Geological Society of America Bulletin, v. 75, p. 107-128.

North American Commission on Stratigraphic Nomenclature, 1983, North American stratigraphic code: American Association of Petroleum Geologists Bulletin, v. 67, p. 841-875.

Stearns, H.T., 1935, Geography and geology, in Stearns, H.T., and Vaksvik, K.N., Geology and groundwater resources of the Island of Oahu, Hawaii: Hawaii Division of Hydrography, Bulletin 1, p. 1-198.

1939, Geologic map and guide of the Island of Oahu, Hawaii: Hawaii Division of Hydrography, Bulletin 2, 75 p. 1940, Supplement to geology and ground-water resources of the Island of Oahu, Hawaii: Hawaii Division of Hydrography, Bulletin 5, $164 \mathrm{p}$.

1946, Geology of the Hawaiian Islands: Hawaii Division of Hydrography, Bulletin 8, $106 \mathrm{p}$. 



\title{
Regional Relations of Upper Silurian-Lower Devonian Rocks, Bossardsville, Eastern Pennsylvania
}

\author{
By Jack B. Epstein
}

\begin{abstract}
Upper Silurian and Lower Devonian rocks southwest of the Wisconsinan terminal moraine in northeastern Pennsylvania are deeply weathered and very poorly exposed. Recent excavation in the Hamilton Stone Company quarry at Bossardsville, Pa., has exposed a complete section of the Decker Formation (Late Silurian) and, for the first time in Cherry Ridge, the Rondout Formation (Late Silurian), as well as saprolitized rocks of the overlying Stormville and New Scotland Formations (Early Devonian). Of the three members of the Rondout Formation that have been mapped in the ridge to the north, the Duttonville and Mashipacong Members can be identified at Bossardsville, and the Whiteport Dolomite Member loses its identity. Reconsideration of a lone deeply weathered exposure 7 miles $(11 \mathrm{~km})$ to the southwest, near Kunkletown, Pa., suggests that the Duttonville pinches out to the southwest as the Mashipacong thickens. The shale and limestone of the Mashipacong then apparently grade into the Andreas Red Beds, 30 miles $(48 \mathrm{~km})$ southwest of Bossardsville at Andreas, $\mathrm{Pa}$. The Coeymans Formation, which consists of four members northeast of Bossardsville (two limestones and two calcareous sandstones and conglomerates), is represented by leached sandstones at Bossardsville and for many miles to the southwest. The sandstone and conglomerate members thicken southwestwardly and replace the limestones at Bossardsville. The Stormville Member is the thickest of these clastic members. It is raised in rank to formation, and the name Coeymans Formation is abandoned for these rocks southwest of Godfrey Ridge.
\end{abstract}

\section{INTRODUCTION}

Upper Silurian through Middle Devonian rocks underlie a line of ridges in eastern Pennsylvania known by various names (fig. 1). These rocks are abundantly exposed in Godfrey Ridge north of the Wisconsinan terminal moraine, and their stratigraphic relations and environments of deposition are well known (Epstein and others, 1967; Epstein, 1973, 1986, in press b). However, south of the moraine, where the rocks have undergone a prolonged period of weathering, exposures are very sparse, and many of the rocks are leached, forming sedimentaryrock saprolites that are more than 100 feet $(30 \mathrm{~m})$ deep
(Epstein and Hosterman, 1969). Until now, the best exposure of Upper Silurian and Lower Devonian rocks southwest of Godfrey Ridge in eastern Pennsylvania has been in a large quarry near Andreas (Lash and others, 1984), where these rocks are thinner, the entire sequence is more clastic than to the northeast, and several of the stratigraphic units pinch out. Recent excavation in the Hamilton Stone Company quarry in the northeastern end of Cherry Ridge at Bossardsville, $\mathrm{Pa}$, has completely exposed the Decker and Rondout Formations, as well as saprolitized rocks of the overlying Stormville and New Scotland Formations, allowing for a revision of previous descriptions. Lithologic details are given of a measured section (table 1), and regional relations are shown in figure 2. Figure 3 shows the lithic components of the Decker and Rondout Formations. Epstein and others (1967) described the Decker Formation, but more details are now available because of better access to the section. Prior to recent excavations, the Rondout was not exposed in the quarry, and there was some question of its existence (Epstein, 1980; Lash and others, 1984, p. 82).

\section{PREVIOUS WORK}

Rogers (1838) first established the stratigraphic sequence of Paleozoic rocks in Pennsylvania. He included Upper Silurian and Lower Devonian rocks in his "Formation No. VI" and later (Rogers, 1858) named these rocks the "Scalent and Pre-Meridian Series." The next major contribution was made by White (1882), who designated the name "Decker's Ferry" for rocks herein assigned to the Decker Formation. These rocks, along with the overlying Rondout Formation and the lower part of the Coeymans Formation (previously named the Manlius Limestone), were later included in the Keyser Limestone or Group by Swartz (1929) and later workers. The confused nomenclatural history was reviewed by Epstein and others (1967), who defined the Decker Formation as consisting of two laterally interfingering members: a limestone facies northeast of north-central New Jersey (Clove Brook Member) and a sandier facies southwestward to 


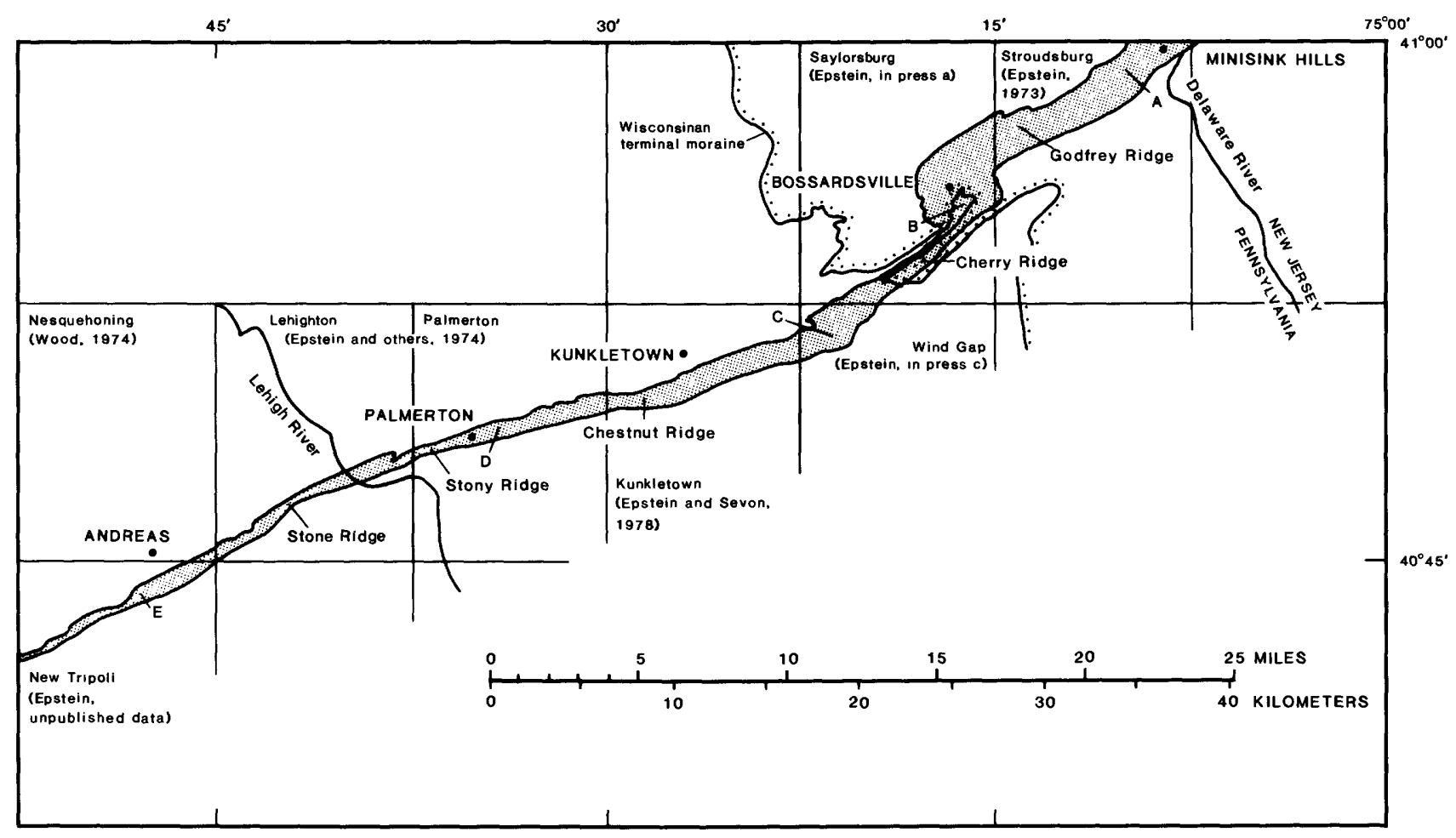

Figure 1. Map showing outcrop belt of Upper Silurian and Lower Devonian (shaded area) in eastern Pennsylvania, the maximum southwest extent of the Wisconsinan glacier, 7.5-minute geologic map coverage, and localities discussed in text. A, Rondout and Coeymans Formations exposed along southeast bank of Brodhead Creek, 3,000 feet $(0.9 \mathrm{~km})$ southwest of Minisink Hills, Pa. (Epstein, 1971, p. 305-307); B, Bossardville Limestone and Decker, Rondout, Stormville, and New Scotland Formations exposed in quarry of H. R. Imbt, Inc., Bossardsville, Pa. (Epstein and others, 1967; see table 1, this report); C, Rondout and Decker Formations exposed in clay pits of Lehigh Portland Cement Company (formerly Universal Atlas Cement Company), 4 miles (6.4 km) northeast of Kunkletown, Pa. (Epstein and Hosterman, 1967); D, easternmost occurrence of float of the Andreas Red Beds near Palmerton, Pa. (Epstein and others, 1974); E, Bossardville Limestone through Stormville Formation exposed in Huss Stone Company quarry, Andreas, Pa. (Lash and others, 1984).

Godfrey Ridge (Wallpack Center Member). Because only the Wallpack Center Member was recognized in eastern Pennsylvania, these rocks were referred to as "the Decker Formation" (Epstein, 1973).

Clarke and Schuchert (1899) named the Rondout Waterlime for rocks overlain by the Manlius Limestone and underlain by Salina beds at Rondout, N.Y. The subsequent nomenclatural history of rocks assigned to the Rondout Waterlime in New York was summarized by Rickard (1962). The nomenclatural changes in Pennsylvania were discussed by Epstein and others (1967), who divided the Rondout into three members.

The Coeymans Formation was named by Clarke and Schuchert (1899) for rocks between the Manlius and New Scotland Limestones at Coeymans, N.Y. Earlier, White (1882) had included strata in eastern Pennsylvania in his Stormville Conglomerate and Limestone that were later correlated with the Coeymans by Grabau (1906). Epstein and others (1967) redefined the Coeymans Formation in eastern Pennsylvania in Godfrey Ridge and recognized four members. One of these members, the Stormville, is raised to formational rank in the area of Bossardsville and southwestward.

The distribution of the strata in eastern Pennsylvania is shown in several geologic maps (Epstein, 1973, 1978, in press a, b, c; Epstein and others, 1974; Wood, 1974; Epstein and Sevon, 1978; Lyttle and Epstein, 1987) (see fig. 1).

\section{DECKER FORMATION}

The type locality of the Wallpack Center Member of the Decker Formation is 1 mile $(1.6 \mathrm{~km})$ northeast of Wallpack Center, N.J., on the southeast slope of Wallpack Ridge, where it is 82 feet $(25 \mathrm{~m})$ thick and mainly consists of calcareous, partly conglomeratic sandstone and arenaceous limestone (Epstein and others, 1967, p. 9). This locality is 27 miles (43 km) northeast of Bossardsville. Epstein and Epstein (1967, 1969), Epstein and others (1967), and Epstein (1980) described the Decker Formation at Bossardsville as consisting of quartzose, argillace ous, and dolomitic limestone, calcareous and conglomer- 
Table 1. Measured section of the Bossardville Limestone and Decker, Roundout, Stormville, and New Scotland Formations in the quarry of H. R. Imbt, Inc., Bossardsville, Pa.

\begin{tabular}{lcc}
\hline Unit & $\begin{array}{c}\text { in } \\
\text { fmeters })\end{array}$ & Description \\
& feet & \\
\hline
\end{tabular}

New Scotland Formation

$5410+(3+)$ Leached, dark-yellowish-orange (10YR6/6) to pale-yellowish-orange (10YR8/6), clayey silt with abundant weathered, light-gray (N7) chert nodules as much as 6 inches $(15 \mathrm{~cm})$ long, and nodular beds of chert as much as 8 inches $(20 \mathrm{~cm})$ thick. Unit was presumably a calcareous shale or shaly limestone. Overlain by Wisconsinan till. Lower contact abrupt.

$10+(3+)$ Incomplete thickness of New Scotland Formation

\section{Stormville Formation}

Leached, dark-yellowish-orange (10YR6/6) to pale-yellowish-orange (10YR8/6) and very pale orange (10YR8/2), quartz-pebble conglomerate with quartz pebbles as much as 0.4 inch $(1 \mathrm{~cm})$ long in a matrix of medium-grained sand. Unit was presumably a calcareous sandy conglomerate.

Leached (presumably was calcareous), dark-yellowish-orange (10YR6/6) to pale-yellowish-orange (10YR8/6) and very pale orange $(10 \mathrm{YR} 8 / 2)$, planar-bedded to crossbedded, fossiliferous (brachiopods (including Gypidula), corals, and crinoids), fine- to medium-grained sand with scattered quartz grains as much as 0.25 inch $(6 \mathrm{~mm})$ long. Lower foot $(0.3 \mathrm{~m})$ consists of fine-grained sand with abundant, irregular, grayish-red (5R4/2) to blackish-red (5R2/2) hematite layers about 1 inch $(2.5$ $\mathrm{cm})$ thick. Lower contact abrupt.

\section{Thickness of Stormville Formation}

\section{Rondout Formation \\ Mashipacong Member}

Leached, cleaved, dark-yellowish-orange (10YR6/6) and light-brown (5YR5/6) to moderate-brown (5YR3/4), mudcracked (mudcrack polygons as much as 8 inches $(20 \mathrm{~cm})$ wide), laminated to thin-bedded shale and silty shale (presumably was calcareous). Lower contact abrupt.

Medium-gray (N5), laminated to thin-bedded, cleaved, fossiliferous (scattered ostracodes), calcareous shale and shaly, very fine grained, arenaceous limestone with scattered quartz grains as much as 0.125 inch (3 mm) long, with scattered laminae of light-olive-gray (5Y6/1) dolomitic shale, and mediumdark-gray (N4) laminae of fine-grained, lenticular, aren aceous limestone. Lower contact gradational.

Medium-gray (N5) to medium-light-gray (N6), thin-bedded, shaly, very fine grained limestone with scattered laminae of rippled, medium-light-gray (N6), very fine grained sandstone. Leached toward top of unit to moderate yellowish brown $(10$ YR5/4) to dark yellowish orange (10YR6/6). Lower contact abrupt.

Medium-light-gray (N6), rippled, fine-grained sandstone. Lower contact abrupt.

\section{Thickness of Mashipacong Member of Rondout Formation}

\section{Rondout Formation \\ Duttonville Member}

Medium-gray (N5), shaly, very fine grained, calcareous dolomite. Lower contact abrupt.

Medium-dark-gray (N4), fossiliferous (ostracodes), pyritiferous, thin-bedded, very fine grained, shaly limestone with interlaminated and interbedded (beds as much as 2 inches $(5 \mathrm{~cm})$ thick), light-olivegray (5Y6/1), very fine grained dolomite. Lower contact abrupt.

Medium-gray (N5), light-olive-gray- (5Y6/1) weathering, massive, very fine grained dolomite. Lower contact abrupt.

Medium-dark-gray (N4), very fine grained, shaly limestone. Lower contact gradational.

(0.2) Medium-gray (N5) to medium-dark-gray (N4), biostromal (stromatoporoids, corals, bryozoans, brachiopods), pyritiferous, fine-grained limestone. Upper 3 inches $(8 \mathrm{~cm})$ is coarse-grained limestone with reworked fossils. Lower contact abrupt.

Medium-dark-gray (N4), shaly limestone leached to light-olive-gray (5Y6/2), platy shale. Lower contact abrupt.

Medium-dark-gray (N4), fossiliferous (abundant bryozoans and some ostracodes), very fine grained limestone, with scattered laminae of light-olive-gray (5Y6/1), grayish-orange- (10YR7/4) weathering, shaly dolomite. Lower contact gradational.

Medium-dark-gray (N4), laminated to thin-bedded, shaly limestone leached to grayish-orange (10YR7/4) shale. Lower contact gradational.

Laminated and irregularly laminated to thin-bedded, medium-dark-gray (N4), fine-grained arenaceous limestone and light-olive-gray (5Y6/1) shaly dolomite and dolomitic shale. Unit weathers pale yellowish orange (10YR8/6) to dark yellowish orange (10YR6/6). Lower contact abrupt.

(0.3) Medium-dark-gray (N4), fossiliferous (ostracode and brachiopod hash), very thin bedded (beds range from 0.5 to 2 inches $(1-5 \mathrm{~cm})$ thick), very fine grained limestone and irregularly laminated, light-olive-gray (5Y6/1) dolomite leached to moderate yellowish brown (10YR5/2). Lower contact gradational. 
Table 1.-Continued.

\begin{tabular}{|c|c|c|}
\hline Unit & $\begin{array}{c}\text { Thickness } \\
\text { in } \\
\text { feet (meters) }\end{array}$ & Description \\
\hline
\end{tabular}

$37 \quad 1.0$

$0 \quad(0.3)$

\section{Duttonville Member-Continued}

Irregularly laminated to thin-bedded, cleaved, medium-dark-gray (N4), arenaceous, fine-grained limestone and light-olive-gray (5Y6/1), shaly dolomite and dolomitic shale. Unit weathers pale yellowish orange (10YR8/6) to dark yellowish orange (10YR6/6).

Light-olive-gray (5Y6/1), leached (presumably was calcareous), cleaved shale. Lower contact abrupt.

Medium-dark-gray (N4), thin-bedded (beds as much as 2 inches $(5 \mathrm{~cm})$ thick), fine- to medium-grained, arenaceous limestone with scattered quartz grains as much as 0.25 inch $(6 \mathrm{~mm})$ long, with irregularly interlaminated light-olive-gray (5Y6/1) dolomite. Lower contact abrupt.

Interbedded, thin-bedded (beds $2.5-5$ inches $(6-13 \mathrm{~cm})$ thick), medium-dark-gray (N4), fossiliferous, arenaceous, medium-grained limestone with scattered quartz grains as much as $0.25 \mathrm{inch}(6 \mathrm{~mm})$ long and lesser dark-gray (N3), shaly limestone. Lower contact gradational.

Medium-dark-gray (N4) to medium-gray (N5), moderate-yellowish-brown- (10YR5/4) to grayishorange- (10YR7/4) weathering, very fine grained, slightly calcareous dolomite. Lower contact abrupt.

Medium-dark-gray (N4), irregularly laminated and thin-bedded, ostracodiferous, very fine to finegrained limestone, interbedded with leached moderate-yellowish-brown (10YR5/4), shaly dolomite. Lower contact abrupt.

Dark-gray (N3), pale-olive-brown- (5Y5/5) weathering, laminated shale, containing slickensides of calcite and quartz. Lower contact abrupt.

Medium-dark-gray (N4), fine-grained limestone with quartz grains as much as 0.25 inch (6 mm) long, grading up to grayish-orange- (10YR7/4) weathering, arenaceous, medium-grained limestone with abundant quartz grains as much as 0.25 inch $(6 \mathrm{~mm})$ long and scattered medium-dark-gray (N4) shale clasts as much as 1 inch $(2.5 \mathrm{~cm})$ long. Some fossil debris. Lower contact abrupt.

Medium-dark-gray (N4), very fine grained, shaly limestone. Lower contact abrupt.

Dark-gray (N3), unevenly laminated and very thin bedded (beds as much as 1.5 inches $(4 \mathrm{~cm})$ thick), ostracodiferous, very fine to fine-grained limestone and medium-gray (N5), mudcracked, unevenly laminated to thin-bedded, dolomitic shale and shaly dolomite that weathers yellowish gray (5Y8/1) and grayish orange (10YR7/4). Lower contact abrupt.

Medium-gray (N5), moderate-yellowish-brown- (10YR5/4) weathering, thin-bedded, calcareous and dolomitic, fine- to medium-grained sandstone with scattered quartz grains and pyrite euhedra as much as 0.25 inch $(6 \mathrm{~mm})$ long. Lower contact abrupt.

Medium-light-gray (N6) to light-bluish-gray (5B7/1), fossiliferous (abundant ostracodes and scattered bryozoans), irregularly thin bedded and laminated, mudcracked, very fine grained, calcareous dolomite and dolomitic limestone. Lower contact gradational.

Greenish-gray (5GY6/1) and medium-gray (N5), grayish-orange- (10YR7/4) weathering, laminated to very thin bedded (beds as much as 1 inch $(2.5 \mathrm{~cm})$ thick), mudcracked, very fine grained dolomite and

calcareous dolomite with scattered ostracodes. Partly covered.
Thin-bedded to laminated, pale-yellowish-green (10GY7/2), grayish-orange-(10YR7/4) weathering dolomite and shale and medium-light-bluish-gray (5B6/1), calcareous, fine-grained sandstone and arenaceous limestone with abundant ostracodes. Mudcracked in upper 1.9 feet $(0.6 \mathrm{~m})$. Many upward-fining cycles averaging 1-2 inches $(3-5 \mathrm{~cm})$ thick of ostracode biosparrudite grading up through arenaceous limestone, fine-grained limestone, and into dolomite. Lower contact gradational. Unit forms caprock over much of quarry.

\section{Thickness of Duttonville Member of Rondout Formation}

\section{Thickness of Rondout Formation}

\section{Decker Formation}

Medium-gray (N5), irregularly thin bedded, very fine to fine-grained, pyritiferous, calcareous sandstone with scattered bryozoans and scattered quartz grains as much as 0.25 inch $(6 \mathrm{~mm})$ long and medium-gray (N5), fossiliferous, fine- to medium-grained limestone. Unit weathers to stripes of grayish orange (10YR7/4) and dark yellowish orange (10YR6/6) in the sandstone and medium light gray (N6) in the limestone. Lower contact gradational.

Medium-gray (N5), very fine grained, calcareous dolomite and medium-dark-gray (N4), fossiliferous (ostracodes and bryozoans), shaly, fine-grained limestone with scattered quartz grains as much as

0.25 inch $(6 \mathrm{~mm})$ long. Lower contact gradational.
(0.3) Medium-dark-gray (N4), irregularly bedded, shaly, very fine to fine-grained limestone with scattered quartz grains as much as 0.25 inch $(6 \mathrm{~mm})$ long and abundant ostracodes. Near top is a dolomite bed that is 0.75 inch $(2 \mathrm{~cm})$ thick. Lower contact gradational.

Medium-dark-gray (N4), calcareous, shaly siltstone with scattered rounded quartz pebbles as much as 0.4 inch $(1 \mathrm{~cm})$ long and with thin (about 1 inch $(2.5 \mathrm{~cm})$ thick), dark-gray (N3), irregular and nodular beds of shaly, ostracodiferous, very fine grained limestone. Lower contact gradational.

(1.2) Interbedded medium-dark-gray (N4), grayish-brownish-orange- (10YR6/4) weathering, irregularly bedded and thin-bedded, calcareous dolomite and medium-dark-gray (N4), ostracodiferous, mediumgrained limestone, both with scattered quartz pebbles as much as 0.4 inch $(1 \mathrm{~cm})$ long. Unit about 70 percent dolomite. Lower contact gradational. 


\begin{tabular}{cc}
\hline Thickness & in \\
Unit & Deet \\
(meters) & Description \\
\hline
\end{tabular}

\section{Decker Formation-Continued}

$18 \quad 1.1 \quad(0.3) \quad$ Medium-dark-gray (N4) to dark-gray (N3), calcareous siltstone to very fine grained sandstone with scattered quartz pebbles as much as 0.4 inch $(1 \mathrm{~cm})$ long. Lower contact abrupt.

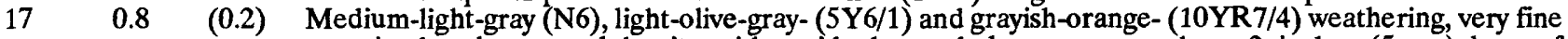
grained, calcareous dolomite with residual rounded areas as much as 2 inches $(5 \mathrm{~cm}) \ln n g$ of undolomitized medium-dark-gray (N4), very fine to fine-grained limestone. Lower contact gradational.

Medium-gray (N5) to dark-gray (N3), medium-gray- (N5) and light-olive-gray- (5Y6/1) weathering, laminated to thin-bedded (beds as much as 4 inches $(10 \mathrm{~cm})$ thick), shaly and silty, very fine grained limestone. Lower contact abrupt.

Laminated to thin-bedded (beds range from less than 0.04 inch $(1 \mathrm{~mm})$ to about 3 inches $(8 \mathrm{~cm})$ thick), medium-dark-gray (N4), fossiliferous (ostracodes, brachiopods, and abundant bryozoans in some beds), shaly, fine- to medium-grained limestone and medium-dark-gray (N4), light-olive-gray(5Y6/1) weathering, slightly calcareous to noncalcareous, shaly siltstone. A 6-inch- (15-cm-) thick interval of siltstone and limestone with abundant bryozoans lies 13 inches $(33 \mathrm{~cm})$ below top. Lower contact gradational.

Medium-dark-gray (N4) to dark-gray (N3), laminated to thin-bedded (beds as much as 4 inches $(10 \mathrm{~cm})$ thick), fossiliferous (crinoid, ostracode, brachiopod, and bryozoan debris), medium- to coarsegrained, arenaceous limestone with rounded quartz pebbles as much as 0.5 inch $(1.3 \mathrm{~cm})$ long, medium-dark-gray $(\mathrm{N} 4)$, very fine grained limestone clasts as much as 2 inches $(5 \mathrm{~cm})$ long, and dark-gray (N3), slightly calcareous shale clasts as much as 3 inches $(8 \mathrm{~cm})$ long. Lower contact abrupt.

Light-gray (N7) to medium-gray (N5), medium- to coarse-grained, channeled and crossbedded (cosets 2-6 inches $(5-15 \mathrm{~cm}$ ) thick), fossiliferous (scattered crinoid columnals), pyritiferous, slightly calcareous quartzite with scattered rounded guartz grains as much as 0.25 inch $(6 \mathrm{~mm})$ long and minor interbedded, moderate-yellow-green $(5 G Y 6 / 2)$, light-olive-gray- $(5 Y 6 / 1)$ weathering shale. Lower contact abrupt.

(3.9) Medium-gray (N5), olive-gray- (5Y4/1) weathering, unevenly laminated to very thin bedded (beds generally from about 0.05 to 1.5 inches $(1-4 \mathrm{~cm})$ thick), slightly shaly and silty, very fine to fine-grained sandstone and medium-light-gray (N6), grayish-orange- (10YR7/4) weathering, fine- to medium-grained, arenaceous limestone and calcareous sandstone. Sandstone makes up about 30 percent of unit at bottom and about 50 percent toward top. Some intervals between 2 and 8 inches $(5$ and $20 \mathrm{~cm})$ thick fill channels as much as 6 feet $(1.8 \mathrm{~m})$ wide. Lower contact gradational.

Medium-dark-gray (N4), poorly bedded, fine-grained, slightly arenaceous and argillaceous limestone and lesser medium-gray (N5), light-olive-gray- (5Y6/1) weathering, irregularly bedded and very thin bedded (beds about 1 inch $(2.5 \mathrm{~cm}$ ) thick), mudcracked dolomite, with scattered ostracodes and scattered dark-gray (N3), subround, very fine grained limestone clasts as much as 2 inches $(5 \mathrm{~cm})$ long. Lower contact gradational.

Irregularly thin bedded and laminated, light-olive-gray (5Y6/1), very fine grained dolomite and medium-dark-gray (N4), fine-grained limestone. Bedding in dolomite near top is disrupted and partly forms angular intraclasts up to about 2 inches $(5 \mathrm{~cm})$ long in limestone. Lower contact abrupt.

Irregularly laminated and discontinuously bedded, light-olive-gray (5Y6/1), very fine grained dolomite and medium-gray (N5) fine-grained limestone, with a 3-inch- (8-cm-) thick bed of medium-dark-gray (N4), very fine grained, slightly calcareous dolomite 2 inches $(5 \mathrm{~cm})$ above base. Lower contact abrupt.

Irregularly laminated, light-olive-gray (5Y6/1), grayish-orange- (10YR7/4) weathering, calcareous dolomite and medium-gray (N5), fossiliferous (ostracodes, brachiopods, and bryozoans), fine-grained limestone. Lower contact gradational.

Medium-light-gray (N6) to light-gray (N7), laminated, shaly, slightly calcareous dolomite. Lower contact gradational.

Irregularly laminated to very thin bedded (beds as much as 0.5 inch $(1.3 \mathrm{~cm})$ thick), grayish-orange(10YR $7 / 4$ ) weathering, medium-gray (N5), fossiliferous (crinoids brachiopods, and ostracodes), fine-grained limestone and greenish-gray (5GY 6/1), mudcracked, calcareous, shaly dolomite. Lower contact gradational.

Laminated to indistinctly laminated and very thin bedded (beds as much as 1.5 inches $(4 \mathrm{~cm})$ thick), mudcracked, grayish-orange- (10YR7/4) weathering, greenish-gray (5GY6/1), very fine grained, shaly dolomite and medium-gray (N5) (with a slight purplish tinge), fossiliferous, fine-grained limestone. Lower contact abrupt.

Irregularly laminated to very thin bedded (beds as much as 2 inches $(5 \mathrm{~cm})$ thick), medium-dark-gray (N4), fossiliferous (ostracodes, brachiopods, and coral fragments), slightly arenaceous, pyritiferous, very fine to medium-grained limestone with quartz grains as much as 0.08 inch $(2 \mathrm{~mm})$ long and greenish-gray (5GY6/1), very irregularly bedded (some beds discontinuous and form angular intraclasts $0.1-2$ inches $(0.3-5 \mathrm{~cm}$ ) long in the overlying limestone), very fine grained dolomite and shaly dolomite. Lower contact gradational and placed at change from laminated beds below to thin beds above.

\section{2 (18.0) Thickness of Decker Formation}


Table 1.-Continued.

\begin{tabular}{|c|c|c|}
\hline Unit & $\begin{array}{c}\text { Thickness } \\
\text { in } \\
\text { feet (meters) }\end{array}$ & Description \\
\hline
\end{tabular}

\section{Bossardville Limestone}

$3 \quad 3.3$ (1.0) Irregularly laminated to very thin bedded (beds as much as 1 inch (2.5 $\mathrm{cm})$ thick), mudcracked, medium-gray (N5), ostracodiferous, shaly, fine-grained limestone and greenish-gray (5GY6/1), shaly, dolomitic limestone. Lower contact gradational.

$2 \quad 6.2$ (1.9) Finely laminated (beds less than 0.04 inch $(1 \mathrm{~mm})$ thick) to very thin bedded (beds as much as 1 inch $(2.5 \mathrm{~cm})$ thick), dark-gray (N3) limestone and medium-gray (N5), dolomitic limestone and dolomite. Many intervals graded. Many microchannels. Mudcracked in upper 2 feet $(0.6 \mathrm{~m})$, where unit is very thinly laminated (algal?). Lower contact gradational.

$15.0+(1.5+)$ Grayish-black (N2) to dark-gray (N3), medium-light-gray- (N6), light-olive-gray- (5GY6/1), to very light-gray- (N8) weathering, laminated, shaly, very thin bedded to laminated (beds as much as 1 inch $(2.5 \mathrm{~cm})$ thick), very fine to fine-grained, pyritiferous, shaly limestone. Many units graded and channeled; some are rippled and crossbedded.

14.5 (4.4) Incomplete thickness of Bossardville Limestone. The Bossardville is completely exposed in quarry and is 94.1 feet $(28.7 \mathrm{~m}$ ) thick (Epstein and others, 1967, p. 71).

atic sandstone, calcareous shale, and minor dolomite. The measurements made during the present study indicate that dolomite is much more abundant. This is unique because, in other exposures in Pennsylvania and New Jersey, dolomite is either a minor constituent or absent. Limestone is the most abundant rock type (about 49 percent), followed by dolomite ( 26 percent), sandstone (19 percent), and siltstone and shale (6 percent) (fig. 3 ). The limestone is dark gray (N3) to medium gray (N5), fine to coarse grained, fossiliferous (ostracodes, bryozoans, brachiopods, crinoids, and corals), laminated to thin bedded, partly argillaceous, arenaceous, and pyritiferous, with scattered quartz pebbles as much as 0.5 inch $(1.3 \mathrm{~cm})$ long. It weathers medium light gray (N6) to medium gray (N5), light olive gray (5Y6/1) to olive gray (5Y4/1), and grayish orange (10YR7/4). Sandstones in the Decker Formation are light gray (N7) to medium dark gray (N4), thin bedded, partly pyritiferous, partly calcareous, very fine to coarse grained, partly channeled, and crossbedded, with scattered quartz pebbles as much as 0.4 inch $(1 \mathrm{~cm})$ long and scattered crinoid columnals, and weather grayish orange (10YR7/4) to dark yellowish orange (10YR6/6). The dolomites are light gray (N7) to medium dark gray (N4) and greenish gray (5GY6/1) to light olive gray (5Y6/1), very fine grained, thin bedded and laminated, partly mudcracked, partly calcareous and shaly, with scattered quartz pebbles as much as 0.4 inch (1 $\mathrm{cm}$ ) long, and weather light olive gray (5Y6/1) and grayish orange (10YR7/4) to grayish brownish orange (10YR6/4). They partially replace some of the limestone beds. A minor part of the Decker is made up of medium dark gray (N4) to dark gray (N3), partly calcareous, shaly siltstone, with scattered quartz pebbles as much as 0.4 inch $(1 \mathrm{~cm})$ long, that weathers light olive gray $(5 Y 6 / 1)$. Moderate-yellow-green $(5 \mathrm{GY} 6 / 2)$ shale that weathers light olive gray (5Y6/1) is an even smaller component of the Decker.

The lower contact of the Decker Formation is placed just above the highest laminated rocks of the Bossardville Limestone. The Bossardville Limestone in the Hamilton Stone Company quarry consists of mostly grayish-black (N2) to medium-gray (N5), irregularly laminated to thin-bedded, graded and microchanneled, partly mud-cracked, ostracodiferous, fine-grained argillaceous limestone and, near the top, dolomitic limestone.

\section{RONDOUT FORMATION}

The Rondout Formation in Godfrey Ridge near Minisink Hills, 8 miles $(13 \mathrm{~km})$ northeast of Bossardsville, consists of three members (Epstein and Epstein, 1967; Epstein, 1971). These are, from oldest to youngest, the Duttonville (interbedded argillaceous limestone, limestone, and dolomite, 11.5 feet $(3.5 \mathrm{~m})$ thick), the Whiteport Dolomite (argillaceous dolomite, 9 feet (2.7 m) thick), and the Mashipacong (calcareous shale and argillaceous limestone, 8 feet $(2.4 \mathrm{~m})$ thick) (Epstein and others, 1967; Epstein, 1971). The three members are recognized 2.3 miles $(3.7 \mathrm{~km})$ northeast of Bossardsville in Godfrey Ridge (Epstein, in press b). Between that locality and Bossardsville, there are no exposures of the Rondout. At Bossardsville, the Duttonville Member has thickened to nearly 35 feet $(11 \mathrm{~m})$, the Whiteport Dolomite Member cannot be distinguished (and the rocks occupying its interval are included within the Duttonville), and the Mashipacong Member has thickened to nearly 17 feet $(5 \mathrm{~m})$.

The Duttonville Member consists of limestone, dolomite, shale, and sandstone. The limestone is medium dark gray (N4) to dark gray (N3), pyritiferous, thin 


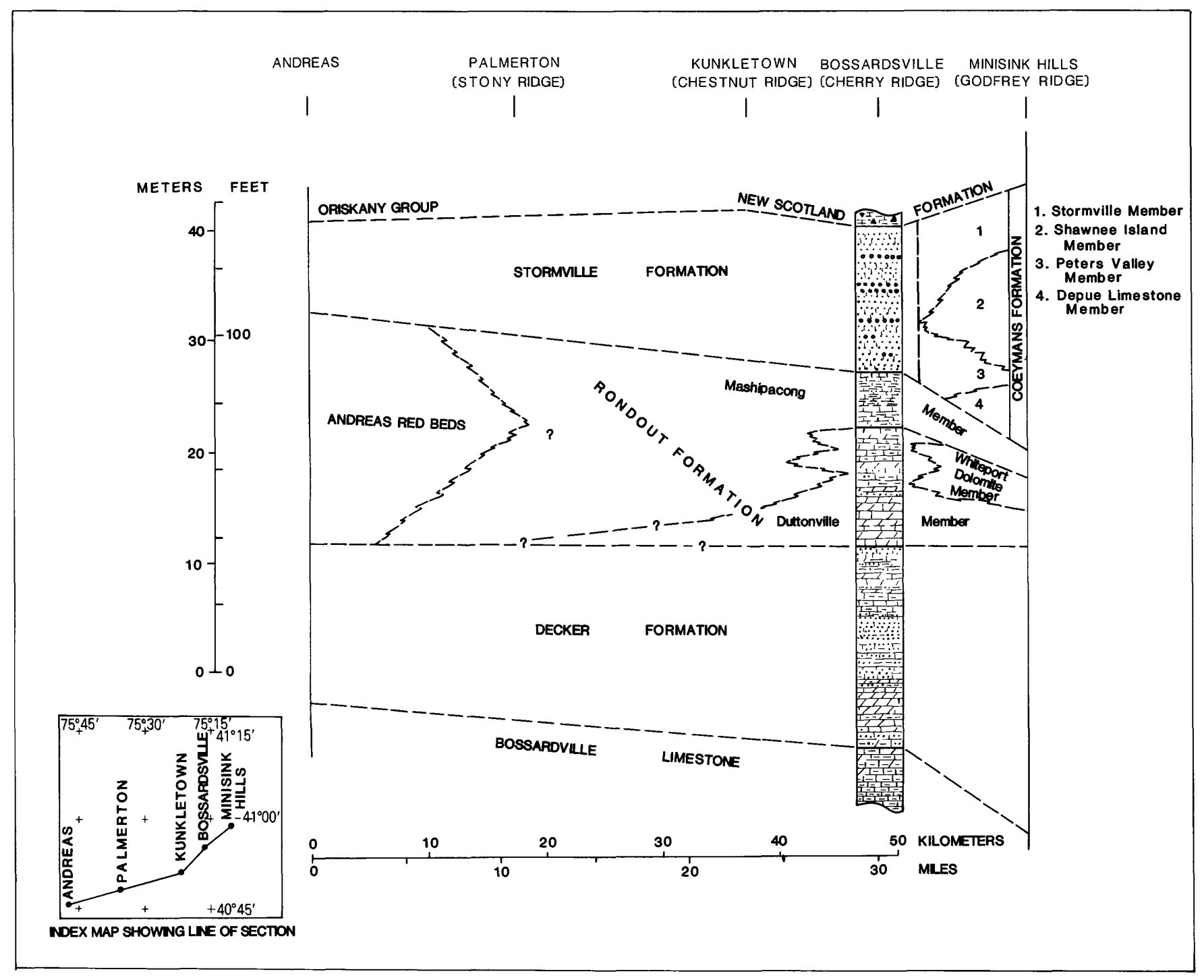

Figure 2. Stratigraphic section of Upper Silurian and Lower Devonian rocks at Bossardsville, Pa., and surrounding region.

bedded to laminated, generally very fine grained (but some beds are as coarse as medium grained), and shaly and contains rare medium-dark-gray (N4) shale intraclasts as much as 1 inch $(2.5 \mathrm{~cm})$ long. The limestone is also partly arenaceous, with rare quartz grains as much as 0.25 inch $(6 \mathrm{~mm})$ long. The dolomite is medium light gray (N6) to medium dark gray (N4), light olive gray (5Y6/1) to greenish gray $(5 \mathrm{GY} 6 / 1)$, light bluish gray $(5 \mathrm{~B} 7 / 1)$, and pale yellowish green (10GY7/2); laminated to thin bedded; partly shaly and calcareous; very fine grained; and partly mudcracked. The shale is dark gray (N3), pale yellowish green (10GY7/2), and laminated. Some of the shale is dolomitic and light olive gray (5Y6/1). The sandstone is medium gray (N5) and light bluish gray (5B6/1), thin bedded, calcareous and dolomitic, and fine to medium grained and contains quartz grains as much as 0.25 inch $(6 \mathrm{~mm})$ long. A 0.5 -foot- $(0.2-\mathrm{m}-)$ thick, fine- grained limestone biostrome with abundant stromatoporoids, corals, bryozoans, and brachiopods, some of which are reworked near the top of the unit, is located 29.5 feet (9 $\mathrm{m})$ above the base of the Duttonville Member. A similar unit, but not necessarily the same one, was seen 7 feet $(2.1 \mathrm{~m})$ above the base of the Duttonville near Minisink Hills (Epstein, 1971, p. 307), as well as farther east into New Jersey (Epstein and others, 1967, p. 13).

At Bossardsville, the Mashipacong Member consists of medium-gray (N5), calcareous, laminated to thinbedded shale and silty shale; medium-gray (N5) to medium-light-gray (N6), shaly and partly arenaceous, very fine grained limestone; and minor fine-grained sandstone and dolomitic shale. The basal contact is placed at the top of the highest dolomite in the Duttonville Member.

The Rondout Formation at Bossardsville contains ostracodes, bryozoans, and brachiopods. It contains many 

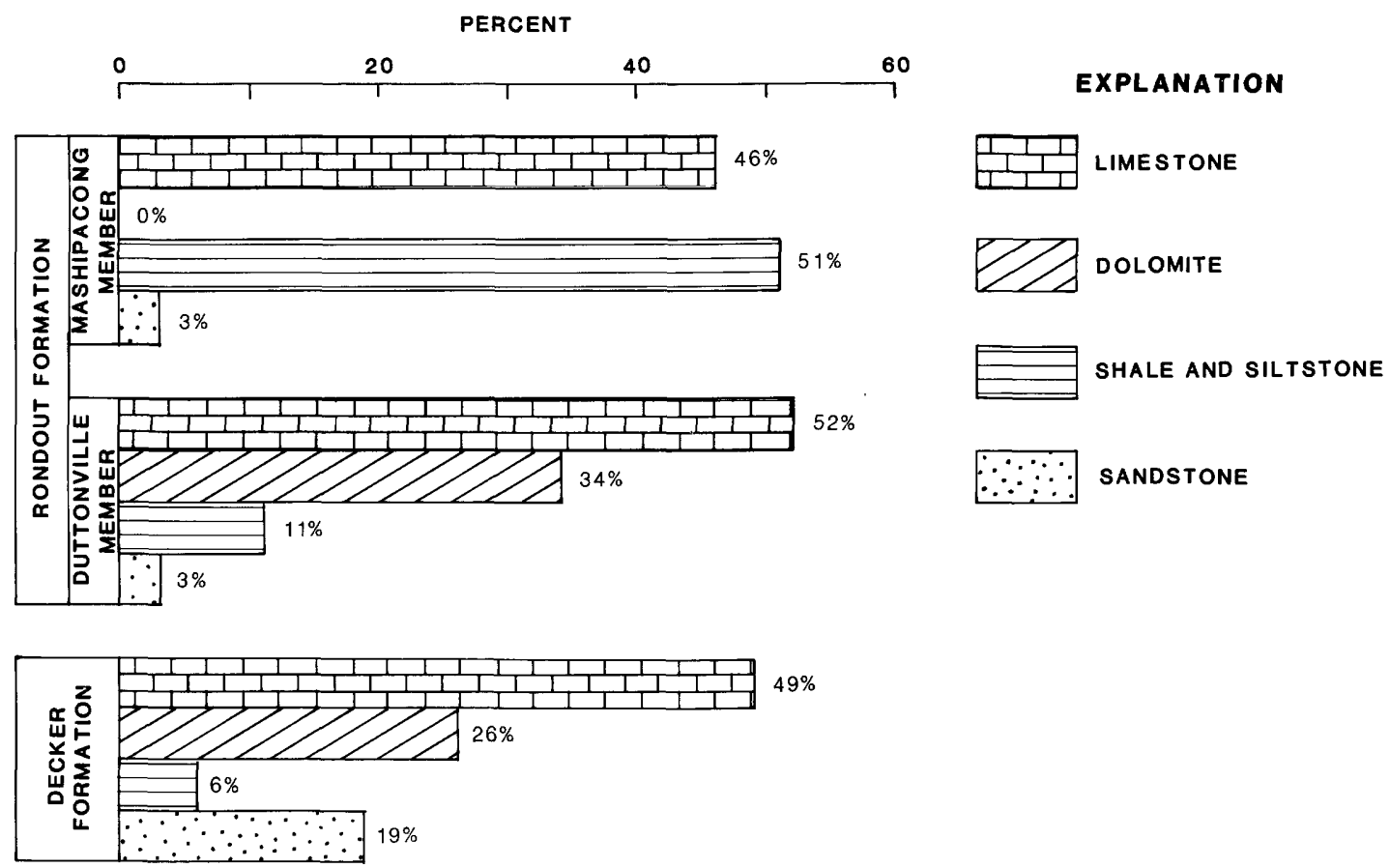

Figure 3. Histogram showing percentage of limestone, dolomite, shale and siltstone, and sandstone in the Decker and Rondout Formations in the Hamilton Stone Company quarry, Bossardsville, Pa.

thin upward-fining units of ostracode biosparrudite grading up through arenaceous limestone and fine-grained limestone and into dolomite. Many of the rocks, especially the shales, are leached from pale yellowish orange (10YR8/6) to moderate brown (5YR3/4) and light olive gray (5Y6/2). Many of the weathered shales probably had all of their calcium carbonate removed by leaching. The lower contact of the Rondout Formation is gradational and placed at the top of the highest sandstone typical of the underlying Decker Formation.

The only possible exposure of the Rondout Formation between Bossardsville and Andreas, $\mathrm{Pa}$, is located in the clay pits of the Lehigh Portland Cement Company (formerly Universal Atlas Cement Company) near Kunkletown, Pa. These deeply leached rocks were placed in the Decker Formation by Epstein and Hosterman (1969), an identification now believed to be incorrect because the regional relationships were poorly known at that time and because underlying rocks were not exposed that would allow the determination of the correct stratigraphic position. The rocks in the clay pits are now assigned to the Mashipacong Member, which consists of 44.4 feet (13.5 m) of very pale orange (10YR8/2) to light-brown (5YR6/4) and dark-yellowish-orange (19YR6/6), silty and very fine sandy clay with rare, floating, rounded quartz grains as much as 0.1 inch ( $3 \mathrm{~mm}$ ) long; grayish-orange (10YR7/4) and moderate-brown (5YR4/4), laminated shale and silty shale with scattered ironstone concretions; and pale-orange (10YR8/4) to dark-yellowish-orange $(10 \mathrm{YR} 6 / 6)$, thin-bedded siltstone and very fine grained sandstone. On the basis of the new exposures at Bossardsville, it is believed that the Rondout changes from mixed dolomite, limestone, and shale at Bossardsville and northeastward, to an interval dominated by calcareous shale at Kunkletown, and then into a red bed sequence at Andreas, 30 miles $(48 \mathrm{~km})$ southwest of Bossardsville (fig. 2). There are no exposures of this interval between Kunkletown and Andreas, so the interfingering relations are unknown. It is possible that the uppermost 15 feet (4.6 $\mathrm{m}$ ) of the Decker Formation at Andreas, consisting of leached, pale-yellowish-orange (10YR8/6) to moderatebrown (5YR4/4) silty clay and shaly siltstone is part of the Mashipacong Member of the Rondout Formation. The Andreas Red Beds at Andreas discussed by Swartz and Swartz (1941) are 69 feet $(21 \mathrm{~m})$ thick and consist of grayish-red (10R4/2), pale-red (5R6/2), and moderatered (5R4/6), partly burrowed, silty shale; shaly siltstone; and pale-red (10R6/2) to dusky-red (5R3/2), grayish-redpurple (5RP4/2), light-gray (N7), and pinkish-gray (5YR8/1) to olive-gray (5Y5/1), pale-brown (5YR5/2) to 


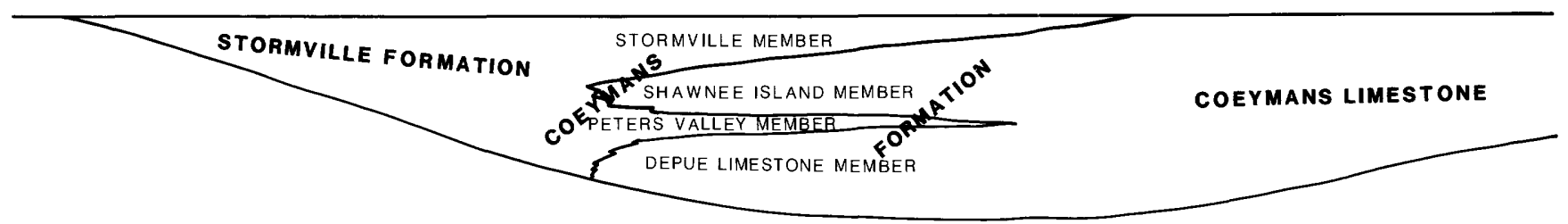

Figure 4. Generalized facies relations between the Coeymans Limestone of New York, the Coeymans Formation of New Jersey and easternmost Pennsylvania, and the Stormville Formation of eastern Pennsylvania.

grayish-orange (10YR7/4), fine- to coarse-grained, thinto medium-bedded, slightly conglomeratic, planar-bedded and crossbedded sandstone with quartz pebbles as much as 0.75 inch $(2 \mathrm{~cm})$ long. These are partly in upwardfining cycles. Most of the rocks in the Andreas are weathered grayish orange (10YR7/4) to moderate yellowish brown (10YR5/4). The Andreas Red Beds at Andreas grade up into the Stormville Formation and overlie the Decker Formation. The Decker Formation at this site is similar to the Decker Formation at Bossardsville, except that dolomite is absent.

\section{STORMVILLE FORMATION}

Abruptly overlying the weathered calcareous shales of the Mashipacong Member of the Rondout Formation at Bossardsville is 43 feet $(13 \mathrm{~m})$ of leached and variably friable, fine- to medium-grained, planar-bedded to crossbedded sandstone and quartz-pebble conglomerate. It is presumed that the unit was mostly a calcareous sandstone and conglomerate and that much calcium carbonate was removed by weathering. Poorly preserved fossils, especially the brachiopod Gypidula coeymanensis, and the position of the unit between the Rondout Formation and overlying leached silt (presumably from a parent calcareous shale) and abundant chert of the New Scotland Formation identify this unit as a correlative of the Coeymans Formation in Godfrey Ridge. The Coeymans Formation was redefined in southeastern New York, New Jersey, and easternmost Pennsylvania by Epstein and others (1967). In Godfrey Ridge, the Coeymans is about 75 feet $(23 \mathrm{~m})$ thick and consists of four members. These are, from oldest to youngest, the Depue Limestone, Peters Valley, Shawnee Island, and Stormville Members (fig. 2). The Depue Limestone and Shawnee Island Members comprise arenaceous and argillaceous fossiliferous limestones. They thin to the southwest into Godfrey Ridge and become more arenaceous and argillaceous. The Peters Valley and Stormville Members contain fossiliferous calcareous sandstone and conglomerate and arenaceous limestone. They thicken gradually from a feather edge in central New Jersey to an aggregate thickness of more than 30 feet $(9 \mathrm{~m})$ in Godfrey Ridge just north of Bossardsville. The rocks in the quarry at Bossardsville are offset to the southeast both perpendicular to the structural grain and landward of the depositional strike by about 1 mile $(1.6 \mathrm{~km})$ by a series of folds (Epstein, in press b). The Coeymans thins in this direction and loses much of its limestone, and the arenaceous component becomes thicker. Thus, the Peters Valley and Stormville Members in Godfrey Ridge thicken southwestwardly and replace the Depue Limestone and Shawnee Island Members at Bossardsville. For this reason, the Stormville (the thicker of the arenaceous members) is raised in rank to formation, as was tentatively suggested by Lash and others (1984, p. 82), and the name Coeymans is abandoned at Bossardsville and to the southwest. The Stormville is recognized at Andreas and possibly extends for at least 20 miles $(32 \mathrm{~km})$ more to Schuylkill Haven, $\mathrm{Pa}$. The Coeymans Limestone of New York and the Stormville Formation of eastern Pennsylvania form a facies mosaic of four interfingering members of the Coeymans Formation in New Jersey and easternmost Pennsylvania. The Stormville and Peters Valley Members of the Coeymans Formation are tongues extending northeastward from the main body of the Stormville Formation, and the Depue Limestone and Shawnee Island Members of the Coeymans Formation are tongues extending southwestward from the main body of the Coeymans Limestone (fig. 4).

\section{CONCLUSIONS}

The Rondout Formation is exposed for the first time in Cherry Ridge in the Hamilton Stone Company quarry at Bossardsville, $\mathrm{Pa}$. The Duttonville and Mashipacong Members persist from Godfrey Ridge in the north, whereas the Whiteport Dolomite Member loses its identity. The Duttonville pinches out southwestward, as the Mashipacong becomes more clastic, and is eventually replaced by the Andreas Red Beds 30 miles $(48 \mathrm{~km}$ ) to the southwest. Sandstones and conglomerates of the Storm- 
ville and Peters Valley Members of the Coeymans Formation thicken from Godfrey Ridge to Cherry Ridge, where they are the dominant lithic type. The Stormville, the thicker of the two clastic members, is therefore raised in rank to formation from Bossardsville southwestward.

\section{REFERENCES CITED}

Clarke, J.M., and Schuchert, Charles, 1899, The nomenclature of the New York series of geological formations: Science, new series, v. 10 , no. 259 , p. $874-878$.

Epstein, A.G., Epstein, J.B., Spink, W.J., and Jennings, D.S., 1967, Upper Silurian and Lower Devonian stratigraphy of northeastern Pennsylvania and New Jersey, and southeasternmost New York: U.S. Geological Survey Bulletin 1243, $74 \mathrm{p}$.

Epstein, J.B., 1971, Geology of the Stroudsburg quadrangle and adjacent areas, Pennsylvania-New Jersey: U.S. Geological Survey Open-File Report 71-95, 339 p.

1973, Geologic map of the Stroudsburg quadrangle, Pennsylvania-New Jersey: U.S. Geological Survey Geologic Quadrangle Map GQ-1047, scale 1:24,000. Includes interpretive text.

1978, Preliminary geologic map of parts of the Saylorsburg quadrangle, Pennsylvania: U.S. Geological Survey Open-File Report 78-170, 2 sheets, scale 1:24,000.

-1980 , Geology of the Ridge and Valley province, northwestern New Jersey and eastern Pennsylvania, in Manspeizer, Warren, ed., Field studies of New Jersey geology and guide to field trips: 52d Annual Meeting New York State Geological Association: Newark, N.J., Rutgers University Press, p. 70-89.

1986, The Valley and Ridge province of eastern Pennsylvania-Stratigraphic and sedimentologic contributions and problems: Geological Journal, v. 21, no. 3, p. 283-306. -in press a, Geologic map of the Saylorsburg quadrangle, Pennsylvania: U.S. Geological Survey Geologic Quadrangle Map GQ-1638, scale 1:24,000.

-in press b, Geologic map of Cherry and Godfrey Ridges, Saylorsburg, Stroudsburg, and East Stroudsburg quadrangles, Pennsylvania: U.S. Geological Survey Miscellaneous Geologic Investigations Map I-1422, scale 1:10,000. Includes descriptive and interpretive text.

-in press c, Geologic map of the Wind Gap quadrangle, Pennsylvania: U.S. Geological Survey Geologic Quadrangle Map GQ-1645, scale 1:24,000.

Epstein, J.B., and Epstein, A.G., 1967, Geology in the region of the Delaware to Lehigh Water Gaps, in Field Conference of Pennsylvania Geologists, 32d, Harrisburg, Pa.: Pennsylvania Geological Survey, $89 \mathrm{p}$.
1969, Geology of the Valley and Ridge province between Delaware Water Gap and Lehigh Gap, Pennsylvania, in Subitzky, Seymour, ed., Geology of selected areas in New Jersey and eastern Pennsylvania and guidebook of excursions: New Brunswick, N.J., Rutgers University Press, p. 132-205.

Epstein, J.B., and Hosterman, J.B., 1969, Residual clay deposits in rocks of Early and Middle Devonian age near Kunkletown, Pennsylvania: U.S. Geological Survey Professional Paper 650-D, p. D95-D105.

Epstein, J.B., and Sevon, W.D., 1978, Preliminary geologic map and sections of the Kunkletown quadrangle, Pennsylvania: U.S. Geological Survey Open-File Report 78-392, 3 sheets, scale $1: 24,000$.

Epstein, J.B., Sevon, W.D., and Glaesser, J.D., 1974, Geology and mineral resources of the Lehighton and Palmerton 7 1/2-minute quadrangles, Pennsylvania: Pennsylvania Geological Survey 4th Ser., Atlas 195cd, 460 p., scale 1:24,000.

Goddard, E.N., and others, 1984, Rock-color chart; Washington, D.C., National Research Council, 6 p. [repub. by Geological Society of America, 1951].

Grabau, A.W., 1906, Guide to the geology and paleontology of the Schoharie Valley in eastern New York: New York State Museum Bulletin 92, p. 77-386.

Lash, G.G., Lyttle, P.T., and Epstein, J.B., 1984, Geology of an accreted terrane: The eastern Hamburg Klippe and surrounding rocks, eastern Pennsylvania, in Field Conference of Pennsylvania Geologists, 49th, Harrisburg, Pa.: Pennsylvania Geological Survey, 151 p. and folded map.

Lyttle, P.T., and Epstein, J.B., 1987, Geologic map of the Newark $1^{\circ} \times 2^{\circ}$ quadrangle, Pennsylvania, New Jersey, and New York: U.S. Geological Survey Miscellaneous Investigations Series Map I-1715, scale 1:250,000.

Rickard, L.V., 1962, Late Cayugan (Upper Silurian) and Helderbergian (Lower Devonian) stratigraphy in New York: New York State Museum Bulletin 386, 157 p.

Rogers, H.D., 1838, Second annual report on the (1st) geological exploration of the State of Pennsylvania: Harrisburg, Pa., 93 p.

1858, The geology of Pennsylvania: A government survey: Philadelphia, Pa., two vols.; 586 and 1046 p.

Swartz, F.M., 1929, The Helderberg Group from central Pennsylvania to southwestern Virginia: Pennsylvania Academy of Sciences, Proceedings, v. 3, p. 75-89.

Swartz, F.M., and Swartz, C.K., 1941, Early Devonian and Late Silurian formations of southeastern Pennsylvania: Geological Society of America Bulletin, v. 52, no. 8, p. 1120-1192.

White, I.C., 1882, The geology of Pike and Monroe Counties: Pennsylvania Geological Survey, 2d ser., Report G6, 407 p.

Wood, G.H., Jr., 1974, Geologic map of the Nesquehoning quadrangle, Carbon and Schuylkill Counties, Pennsylvania: U.S. Geological Survey Geologic Quadrangle Map GQ-1132, scale 1:24,000. 



